Prepared For:

Department of Energy

\title{
CHEMICAL SIGNATURES OF AND PRECURSORS TO FRACTURES USING FLUID INCLUSION STRATIGRAPHY
}

DOE Award Number: DE-FG36-08G018188 A002

Team Members:

Hattenburg Dilley \& Linnell , LLC Energy Geoscience Institute

\section{Authors:}

Lorie M. Dilley

Date: March 30, 2011 


\section{EXECUTIVE SUMMARY}

Fluid Inclusion Stratigraphy (FIS) is a method developed for the geothermal industry which applies the mass quantification of fluid inclusion gas data from drill cuttings to evaluate fluid barriers in modern geothermal systems. This project was designed to further develop the method to use key gas signatures to identify fractures in geothermal systems. Our hypothesis is that peaks in gas concentrations are related to fracture locations. The primary goal was to determine which chemical species could be used to identify fracture locations and evaluate the FIS signature in terms of the mineralogy and geology of various fields. Through the use of spatial relationships and statistical analysis it was shown that there is a statistical difference between the average gas concentration in select species between fracture and non-fracture areas. Useful species include $\mathrm{H}_{2}, \mathrm{H}_{2} \mathrm{~S}, \mathrm{CO}_{2}$, and $\mathrm{SO}_{2}$. Other species would also be useful but to a lower confidence level. In addition, ratios of $\mathrm{CO}_{2} / \mathrm{N}_{2}$ and $\mathrm{CO}_{2} / \mathrm{H}_{2}$ appear to work well particularly in wells where boiling is evident. Although a routine was not developed to specifically identify fracture locations given a set of data, the statistical analysis and spatial relationships observed provide a suggestion that a routine could be developed. Mineral assemblages and geology of the field affect which chemical species was most useful. In Steamboat Springs which has sulfide mineralogy, $\mathrm{H}_{2} \mathrm{~S}$ was more useful and had a greater average in fracture areas than in non-fracture areas. The statistical analysis also showed that there was a significant statistical difference in the average concentration with $\mathrm{H}_{2} \mathrm{~S}$ in fracture and non-fracture areas. Similar results were achieved with $\mathrm{CO}_{2}$ and the use of the ratio $\mathrm{CO}_{2} / \mathrm{N}_{2}$. The ability to identify fractures in a well once it is drilled prior to well testing and development would aid in evaluating the potential of a well for fracture stimulation and in developing an enhanced geothermal system. 


\section{TABLE OF CONTENTS}

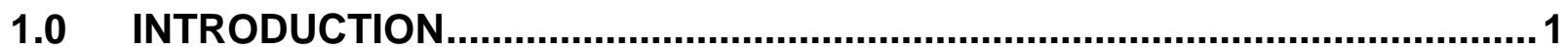

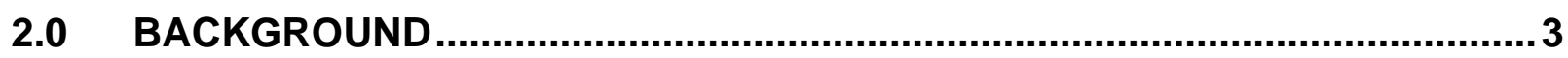

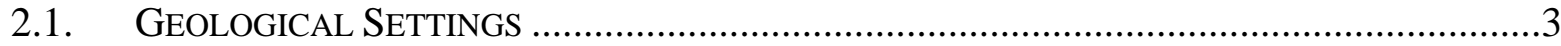

2.1.1. Karaha-Telaga Bodas......................................................................... 4

2.1.2. Glass Mountain KGRA ......................................................................4

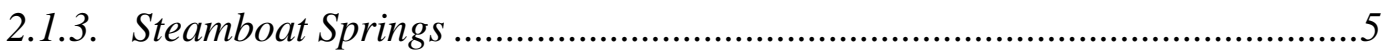

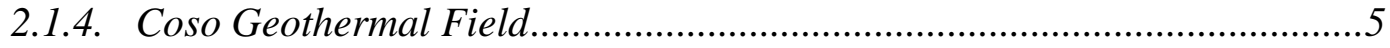

2.1.5. Preliminary Study Results...........................................................6

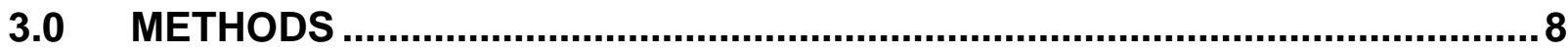

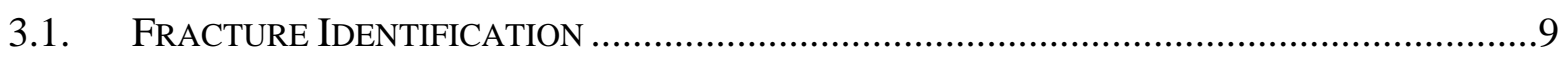

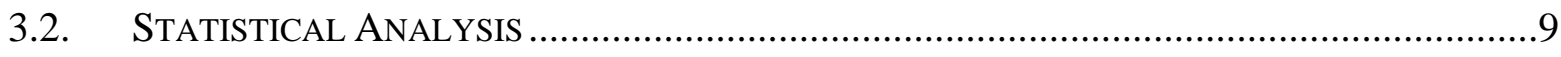

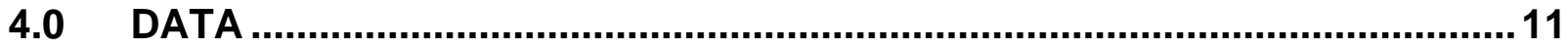

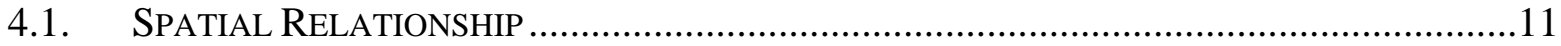

4.1.1. Steamboat Springs Well 87-29...............................................................11

4.1.2. Karaha Well T2..................................................................................13

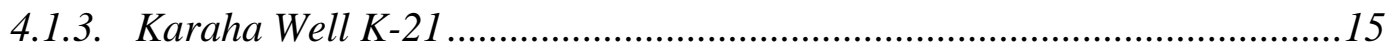

4.1.4. Karaha Well K-33.............................................................................17

4.1.5. Glass Mountain Well GMF 17A-6 .....................................................19

4.1.6. Glass Mountain Well 88-28 ..............................................................21

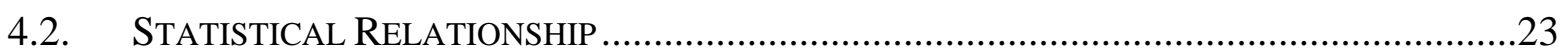

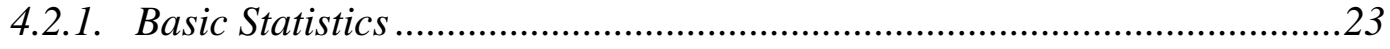

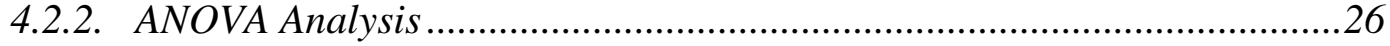

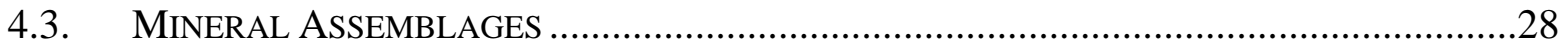

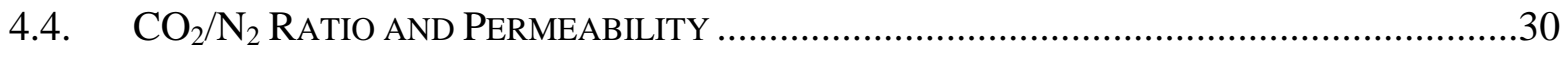

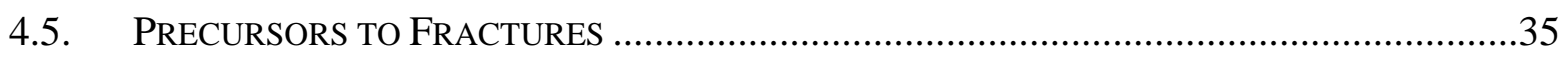

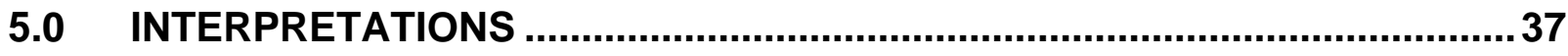

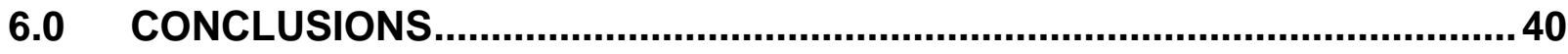

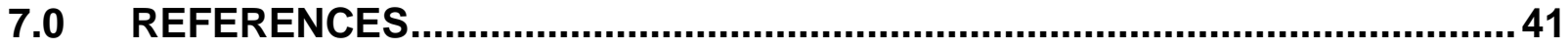




\section{LIST OF FIGURES}

Figure 1: Typical FIT mass spectra of fluid inclusions in drill chips from a particular depth.

Figure 2: FIS Log for Steamboat Springs Well 87-29....................................... 12

Figure 3: FIS Log for Karaha Well T-2. A vapor zone begins at approximately 3000 feet in the well. ............................................................................... 14

Figure 4: FIS Log for Karaha Well K-21 ....................................................... 16

Figure 5: FIS Log for Karaha Well K-33 ........................................................ 18

Figure 6: FIS Log for Glass Mountain Well GMF 17A-6...................................... 20

Figure 7: FIS Log for Glass Mountain Well 88-28........................................... 22

Figure 8: Comparison of means for fracture and non-fracture areas for select chemical species for Well 87-29. For $\mathrm{CO}_{2}$ there is a statistical difference between fracture and non-fracture areas however for $\mathrm{H}_{2} \mathrm{O}$ there is not a statistical difference.

Figure 9: Photographs of the occurrence of calcite and quartz in Steamboat Springs Well 87-29.

Figure 10: Photographs of the occurrence of pyrite in Karaha Well T-2 ...................29

Figure 11: Photographs of calcite occurrence in Glass Mountain Well 88-28............30

Figure 12: $\mathrm{CO}_{2} / \mathrm{N}_{2}$ ratio versus percent total gas plots. Trends for boiling and condensation.

Figure 13: Plot of change in ratio with lost circulation, dikes and altered zones for Coso well 68-20.

Figure 14a: Specific fracture locations in Well T2. The plots are of the concentrations of $\mathrm{CO}_{2}$ shown in red, $\mathrm{H}_{2} \mathrm{O}$ shown in blue, and $\mathrm{H}_{2} \mathrm{~S}$ shown in yellow.........35

Figure 14b: Fracture locations for Well 88-28. The plots are of the concentrations of $\mathrm{CO}_{2}$ shown in red, $\mathrm{H}_{2} \mathrm{O}$ shown in blue, and $\mathrm{H}_{2} \mathrm{~S}$ shown in yellow. 36 


\section{LIST OF TABLES}

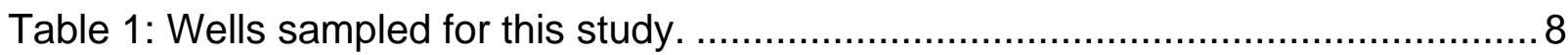

Table 2: Basic statistics per well for fracture and non-fracture areas for

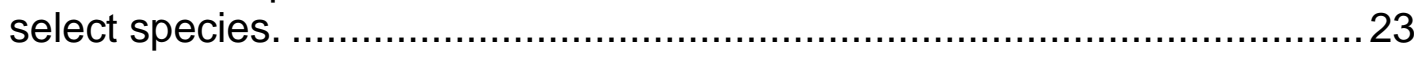

Table 3: Summary of ANOVA Statistics for five wells. ..........................................2 27

Table 4: ANOVA Summary for Permeability Ratios ................................................... 34

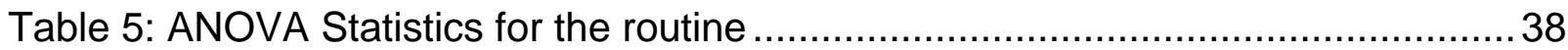




\subsection{INTRODUCTION}

Enhanced Geothermal Systems (EGS) are designed to recover heat from the subsurface by mechanically creating fractures in subsurface rocks. Open or recently closed fractures would be more susceptible to enhancing the permeability of the system. Identifying dense fracture areas as well as large open fractures from small fracture systems will assist in fracture stimulation site selection. Geothermal systems are constantly generating fractures (Moore, Morrow et al. 1987), and fluids and gases passing through rocks in these systems leave small fluid and gas samples trapped in healed microfractures. These fluid inclusions are faithful records of pore fluid chemistry. Fluid inclusions trapped in minerals as the fractures heal are characteristic of the fluids that formed them, and this signature can be seen in fluid inclusion gas analysis. This report presents the results of the project to determine fracture locations by the chemical signatures from gas analysis of fluid inclusions. With this project we hope to test our assumptions that gas chemistry can distinguish if the fractures are open and bearing production fluids or represent prior active fractures and whether there are chemical signs of open fracture systems in the wall rock above the fracture.

Fluid Inclusion Stratigraphy (FIS) is a method developed for the geothermal industry which applies the mass quantification of fluid inclusion gas data from drill cuttings and applying known gas ratios and compositions to determine depth profiles of fluid barriers in a modern geothermal system (Dilley, 2009; Dilley et al., 2005; Norman et al., 2005). Identifying key gas signatures associated with fractures for isolating geothermal fluid production is the latest advancement in the application of FIS to geothermal systems (Dilley and Norman, 2005; Dilley and Norman, 2007).

Our hypothesis is that peaks in FIS data are related to location of fractures. Previous work (DOE Grant DE-FG36-06GO16057) has indicated differences in the chemical signature of fluid inclusions between open and closed fractures as well as differences in the chemical signature of open fractures between geothermal systems. Our hypothesis is that open fracture systems can be identified by their FIS chemical signature; that there are differences based on the mineral assemblages and geology of the system; and that there are chemical precursors in the wall rock above open, large fractures.

Specific goals for this project are:

- To build on the preliminary results which indicate that there are differences in the FIS signatures between open and closed fractures by identifying which chemical species indicate open fractures in both active geothermal systems and in hot, dry rock.

- To evaluate the FIS signatures based on the geology of the fields.

- To evaluate the FIS signatures based on the mineral assemblages in the fracture. 
- To determine if there are specific chemical signatures in the wall rock above open, large fractures.

This method promises to lower the cost of geothermal energy production in several ways. Knowledge of productive fractures in the boreholes will allow engineers to optimize well production. This information can aid in well testing decisions, well completion strategies, and in resource calculations. It will assist in determining the areas for future fracture enhancement. This will develop into one of the techniques in the "tool bag" for creating and managing Enhanced Geothermal Systems.

This project is funded by the Department of Energy (DOE), Enhanced Geothermal Systems Technology Development program. The DOE award number is DE-FG36-08G018188. 


\subsection{BACKGROUND}

Fluid Inclusion Stratigraphy (FIS) is based on interpreting fluid sources from fluid inclusion gas analysis. Temperatures and composition of geothermal fluids are sensitive indicators of their origins, evolutions, and the processes that have affected them. Mass spectrometer analyses of gases within these inclusions have shown fluid sources and processes within geothermal systems (Norman et al.; 1997; Dilley et al., 2004; Dilley and Norman, 2004; Norman et al., 2005). FIS is focused on determining fluid types (plume, condensate, meteoric, or background) from the drill cutting fluid inclusions. We have had some success in determining producing zones from non-producing zones as well as identifying zones where cold water entrants occurring along the borehole (Dilley and Norman, 2004). FIS analyses plotted on mud logs show significant peaks and valleys. We further assumed that near fractures, the primary signature is recorded, not background or previous events, because we assume fluid inclusion planes are reopened during a local fluid event, and that in highly strained rock, fluid inclusions are destroyed. We have shown that these peaks on FIS logs correlate in space with fractures as identified in three wells (Dilley et al., 2008). We also have preliminary results that there is a difference between open and closed fractures in FIS signatures. Based on the fluid inclusion thermometry and FIS analysis conducted there are halo zones of fluid inclusions around fractures. Fluids and gases have migrated into the wall rock and may indicate open fractures.

Previous phases of this research verified that peaks in FIS data were often spatially associated with fractures, especially open fractures. The current work includes statistical analysis to quantitatively identify which fluid inclusion gas peaks (which chemical signatures) are associated with open and closed fractures in varying geologic regimes and lithologies. In addition, we have correlated lost circulation zones with the change in the $\mathrm{CO}_{2} / \mathrm{N}_{2}$ ratio to confirm the use of this ratio in determining permeability of a well.

\subsection{Geological Settings}

Cores from three different fields had been logged and sampled: three each from Karaha-Telaga Bodas (Karaha), Glass Mtn. and Steamboat Springs geothermal fields. In addition, well chips from Coso geothermal field were sampled from 21 wells for previous studies. These 21 wells had drill logs that identified mineral assemblages and lost circulation zones. Karaha in Indonesia is an active, single geothermal event at an active volcano. Glass Mountain in California is a single geothermal event system at the edge of the Basin and Range and more volcanic in nature than Steamboat Springs. Steamboat in Nevada is a classic Basin and Range, geothermal system with multiple events. Coso in California is also a Basin and Range geothermal system with evidence for 3 events over the last 300,000 years. 


\subsubsection{Karaha-Telaga Bodas}

Karaha-Telaga Bodas (Karaha) is a vapor dominated geothermal system on the Island of Java in Indonesia (Nemcock et al., 2004). The geothermal field follows a volcanic ridge that stretches between Kawah Galungung and Kawah Karaha. The history of this system is considered to be relatively simple, as indicated by vein paragenesis (Moore et al. 2002). An initial liquiddominated stage began when magma intruded the base of the volcanic cone. The geothermal system was capped by volcanic extrusives (lava and pyroclastic flows). Probably due to the catastrophic slope failure that formed Galunggung crater approximately 4200 years ago, the system experienced a sudden drop in fluid pressures that boiled the fluids of the system and resulted in the vapor dominated system encountered today. Downward percolating condensate and meteoric waters resulted in progressive downward sealing of fractures that extended the depth of the cap rock. Decreased pore pressure in the vapor zone caused collapse of fractures and left low permeability. The present day system has been explored by drilling to depths of 1.86 miles. The vapor dominated system overlies a deeper liquid reservoir and temperatures up to $660^{\circ} \mathrm{F}$ are measured. A quartz diorite encountered at depth in drill holes is believed to be the intrusive supplying heat to the system (Moore et al., 2002). Well T2 was advanced to a depth of 4,400 feet on the northern side of Telaga Bodas (Figure 2) in 1997. The well was shallow and did not penetrate the magmatic vapor chimney but did below 3,000 feet (ft) encounter a vapor-dominated zone. The well encountered a series of lithic tuffs and andesitic tuffs. Temperatures dramatically increased at approximately $2,200 \mathrm{ft}$. from below $200^{\circ} \mathrm{F}$ to slightly above $500^{\circ} \mathrm{F}$. Well K21 occurs in the southern portion of the field and is liquid dominated. This well may have encountered vapor-dominated zones near the bottom of the well. Well K33 is located in the central portion of the field and is more vapor-dominated than liquid-dominated (Moore et al., 2008). Both liquid and vapor-rich inclusions were observed in the microthermometric measurements performed on Karaha samples. Large primary vapor-rich inclusions were common in many samples indicating boiling occurred (Moore et al., 2008).

\subsubsection{Glass Mountain KGRA}

The Glass Mountain known Geothermal Resource Area (Glass Mtn.) is located on Medicine Lake Volcano in the Cascade Range of Northern California. Medicine Lake Volcano (MLV) is a shield volcano just east of the main arc of the Cascades in a basin and range-style E-W extensional environment on the Modoc Plateau. Regional N-S trending normal faults project under the volcano from the north and the south. The northwestern extension of the Walker Lane fault system also coincides with MLV (Donnelly-Nolan, 2002). Volcanic activity at MLV seems to be strongly episodic, with the most recent episode ending about 900 years ago with the eruption of dacite and rhyolite at Glass Mountain and other east rim vents (Donnelly-Nolan, 1990). MLV is the largest volcano by volume in the Cascades, and earlier volcanic vents connect MLV with Mt. Shasta, about $50 \mathrm{~km}$ to the west-southwest. Vent and fault alignments on MLV are generally N-S and rarely outside of 30 degrees of north (Donnelly-Nolan, 1990). 
Lavas range in composition from basalt through rhyolite. Glass Mountain on the upper east flank of MLV is a rhyolite dome complex with rhyolite and dacite obsidian flows. It is believed that MLV is made up of many small, differentiated magma bodies and a complex of mafic dikes from the periodic injection of basalt, which ultimately provides the volcano's heat. Well 88-28 is composed of felsic volcanics overlying mafic lavas. The well was advanced to a total depth of $8,000 \mathrm{ft}$. however core was available for only the top 3,600 ft. At approximately 1,200 ft. the lithology changes from mixed volcanics (altered basalts) to felsic volcanics. The estimated static temperature increases rapidly from $350^{\circ} \mathrm{F}$ at $1500 \mathrm{ft}$. to $400^{\circ} \mathrm{F}$ at $2800 \mathrm{ft}$. Well GMF $17 \mathrm{~A}-6$ was advanced to 9,600 feet and encountered inter-layered volcanics, contact metamorphics and granodioritic rocks (Carrier 1989).

\subsubsection{Steamboat Springs}

Steamboat Springs (Steamboat) is located in the Humboldt zone of the Basin and Range in northern Nevada. The Humboldt zone is a northeast-trending structural zone containing northeast-striking left-lateral and normal faults and northeast-trending folds. Several major geothermal fields lie in this zone (Faulds et al., 2002). North and northeast striking faults in the Steamboat area likely provide conduits for fluid flow.

Several 1.1 million year-old rhyolite domes occur in the area, another rhyolite intrusive may lie under the thermal area (White et al., 1964). The area has been hydrothermally active, at least intermittently, for over 2.5 million years (Silberman et al., 1979). There is debate about whether the hydrothermal system is due to circulation of fluids in an extensional environment or due to heat from a magmatic intrusion at depth. Both types of hydrothermal systems are present in the Basin and Range, and the extensional type system is nearly unique to this environment. Support for an extensional heat mechanism comes from close proximity to an active range front fault. Although there is no direct evidence for a magmatic system able to provide the needed heat, geochemical data supports this option, in a manner called "compelling" by the authors (Ahehart et al., 2003). The known rhyolite domes are too old to have provided this heat source, but younger intrusions may be buried.

Well 87-29 was advanced to a depth of $3990 \mathrm{ft}$. The matrix is composed of lahars, and a series of granodiorites. Primary production is from 500 to $1200 \mathrm{ft}$. with temperatures above $300^{\circ} \mathrm{F}$.

\subsubsection{Coso Geothermal Field}

The Coso geothermal system is within the western extent of the Basin and Range province and occupies approximately 30 square kilometers of the Mojave Desert. The reservoir has sustained $240 \mathrm{MW}$ of electricity from fractured Mesozoic rocks that consist primarily of granitic plutons and metamorphics. Pliocene and Pleistocene volcanics with an age range of 4 to 0.04 $\mathrm{Ma}$ overlie the Mesozoic rocks. The geology of the Coso area results from the complex interaction of Basin and Range extensional forces with the right-lateral strike slip movement of 
the San Andreas Fault system. Pliocene and Pleistocene volcanic rocks are the most voluminous and widespread of the rocks in the area. There are approximately $400 \mathrm{~km}^{3}$ of lava flows and domes. The relationship of the volcanic rocks to the underlying granitic basement was documented by Duffield et al. in 1980. Sugar Loaf Mountain is a rhyolite dome in the middle of the Coso field, surrounded by a series of basalt rocks. The older granitic and metamorphic rocks of the Sierra Nevada's and the Argus Range are both to the east and to the west of the Coso field. The Pleistocene volcanic rocks consist of 38 separate domes and flows of high-silica rhyolite, and most of them are quite young; younger than 300,000 years. Bacon et al. (1981) inferred from the rhyolite magma that there was a chemically stratified siliceous reservoir at depth. Most of the first production of the geothermal system was near Dome 53, which is near the Devil's Kitchen fumarolic area. The distribution of the siliceous vents and the volume of extruded magma combined with interpretations from geophysical measurements indicate that the siliceous magma body is approximately $5 \mathrm{~km}$ in diameter and more than $1 \mathrm{~km}$ thick, with a total volume of about 20 to 30 cubic $\mathrm{km}$ (Bacon et al. 1980). This magma body probably underlies the Coso volcanic field by a depth of at least $8 \mathrm{~km}$ and is thought to be still partially melted, based on most recent basaltic eruptions occurring as late as a few thousand years ago.

The Coso geothermal system is a volcanic-hosted system. On the basis of the rocks observed on the surface, there appear to have been three episodes of thermal activity. Fossil fumaroles (travertine deposits) on the eastern side of the field are dated using U/Th dating to 307,000 years old and represent the first episode of thermal activity (Adams et al. 2000). Sinter deposits dated at about 238,000 years old in the eastern and southern parts of the present-day field record the second episode. The most recent thermal episode began approximately 10,000 years ago (Kurilovich et al. 2003), based on potassium/argon dating of well chip samples. Fluid inclusion data from Lutz (1999) suggest that the first episode was a large-scale system but of low to moderate temperature. The second episode was produced by magmatic activity beneath the dome field that resulted in a large high-temperature system. The most recent event has heated up the eastern flank by $212^{\circ} \mathrm{F}\left(100^{\circ} \mathrm{C}\right)$ and reactivated the high-temperature center beneath the southern part of the field.

\subsubsection{Preliminary Study Results}

Results from the preliminary study (Dilley, Norman and Owens, 2008) indicate the following:

1) The bulk analysis of volatiles within fluid inclusions appears to correspond with several types of fracture infilling minerals including quartz, calcite, and pyrite.

2) Fluid inclusion $\mathrm{H}_{2} \mathrm{O}$ concentrations increase significantly in felsic and/or crystalline rocks. In rocks such as at Steamboat concentrations of $\mathrm{H}_{2} \mathrm{O}$ occurred throughout the well and varied in peak height. In Glass Mtn. and Karaha, $\mathrm{H}_{2} \mathrm{O}$ did not occur in the 
basaltic rock zones and only occurred to vary in concentration in the more felsic rocks in both wells.

3) The concentration of $\mathrm{H}_{2} \mathrm{O}$ correlated with fractures, veins and vugs in the felsic rocks in Glass Mtn. and Karaha. In Steamboat where the $\mathrm{H}_{2} \mathrm{O}$ was more pervasive, the concentration of $\mathrm{H}_{2} \mathrm{O}$ did not always correlate with fractures, veins and vugs.

4) Fluid inclusion total gas concentration correlated with fractures in the three wells. Significant peaks in the total gas concentration occurred with select fractures in the three wells.

5) The fluid inclusion concentration of $\mathrm{CO}_{2}, \mathrm{H}_{2} \mathrm{O}, \mathrm{Ar}, \mathrm{N}_{2}$ and sulfur species appear to on the FIS logs, increase significantly when the fractures, veins and vuggy areas are in a producing zone or zone of higher temperatures suggesting active, open fractures.

6) The fluid inclusion concentration of heavier organics appear to on the FIS logs be higher in zones that would have fractures that were older and closed for a length of time. 


\subsection{METHODS}

Cores and well chips were collected from the wells detailed in Table 1. The cores and well chips are located at the Energy \& Geoscience Institute in Salt Lake City, Utah. A continuous log of fractures, veins, fracture systems, and alterations was made for each core. The Coso wells sampled had drill logs that identified mineral assemblages and lost circulation zones. FIS samples were collected every 30 feet along the core and every 10 feet where there were fractures, veins, and fracture systems. FIS samples were collected at 20-foot intervals in the Coso wells during a previous study. Select zones that contained fractures had FIS samples collected every 2 feet. FIS samples collected were submitted to Fluid Inclusion Technology (FIT) of Oklahoma for analysis.

Table 1: Wells sampled for this study.

\begin{tabular}{|c|c|c|c|}
\hline Geothermal Field & Well Name & Core/Well Chip & Depth Sampled \\
\hline Karaha & T2 & Core & $1,206-4,536$ \\
\hline Karaha & K21 & Core & $805-4,310$ \\
\hline Karaha & K33 & Core & $2,480-6,617$ \\
\hline Glass Mtn. & $88-28$ & Core & $1,200-3,580$ \\
\hline Glass Mtn. & GMF 17A-6 & Well Chips & $100-9,620$ \\
\hline Steamboat Springs & $87-29$ & Core & $20-4,032$ \\
\hline
\end{tabular}

Samples were collected from the core by first obtaining a piece of the core and then crushing it to approximately a sand size. The well chips were sampled directly from the well chip sample bags. No further crushing of the well chips was conducted prior to submission to FIT. The sample size was approximately 10 grams. FIT has a proprietary system for rapid bulk analysis of fluid inclusion gases (Hall, 2002). A sample is crushed in a vacuum and the volatiles are analyzed with a quadrupole mass spectrometer. The raw data is in the form of an Excel spreadsheet with relative concentrations per mass peak from 2 to 180. See Dilley et al., 2005, Dilley, 2009, Norman et al., 2005, for more on the FIS analysis process.

The species of interest are the principal gaseous species in geothermal fluids and trace hydrocarbon species, which include $\mathrm{H}_{2}, \mathrm{He}, \mathrm{CH}_{4}, \mathrm{H}_{2} \mathrm{O}, \mathrm{N}_{2}, \mathrm{H}_{2} \mathrm{~S}, \mathrm{Ar}, \mathrm{CO}_{2}, \mathrm{C}_{2} \mathrm{H}_{4}, \mathrm{C}_{2} \mathrm{H}_{6}, \mathrm{C}_{3} \mathrm{H}_{6}$, $\mathrm{C}_{3} \mathrm{H}_{8}, \mathrm{C}_{4} \mathrm{H}_{8}, \mathrm{C}_{4} \mathrm{H}_{10}$, benzene, and toluene. Geothermal fluid inclusion mass spectra generally show major peaks at $2\left(\mathrm{H}_{2}\right), 18\left(\mathrm{H}_{2} \mathrm{O}\right), 28\left(\mathrm{~N}_{2}\right)$ and $44\left(\mathrm{CO}_{2}\right)$, with other mass spectra at lower values. The peaks at high mass/electron values (above about 60) are typically heavier organic compounds. Intensities range up to 8 orders of magnitude. Figure 1 presents that mass spectra for one sample at a particular depth from a well at Coso geothermal field. 


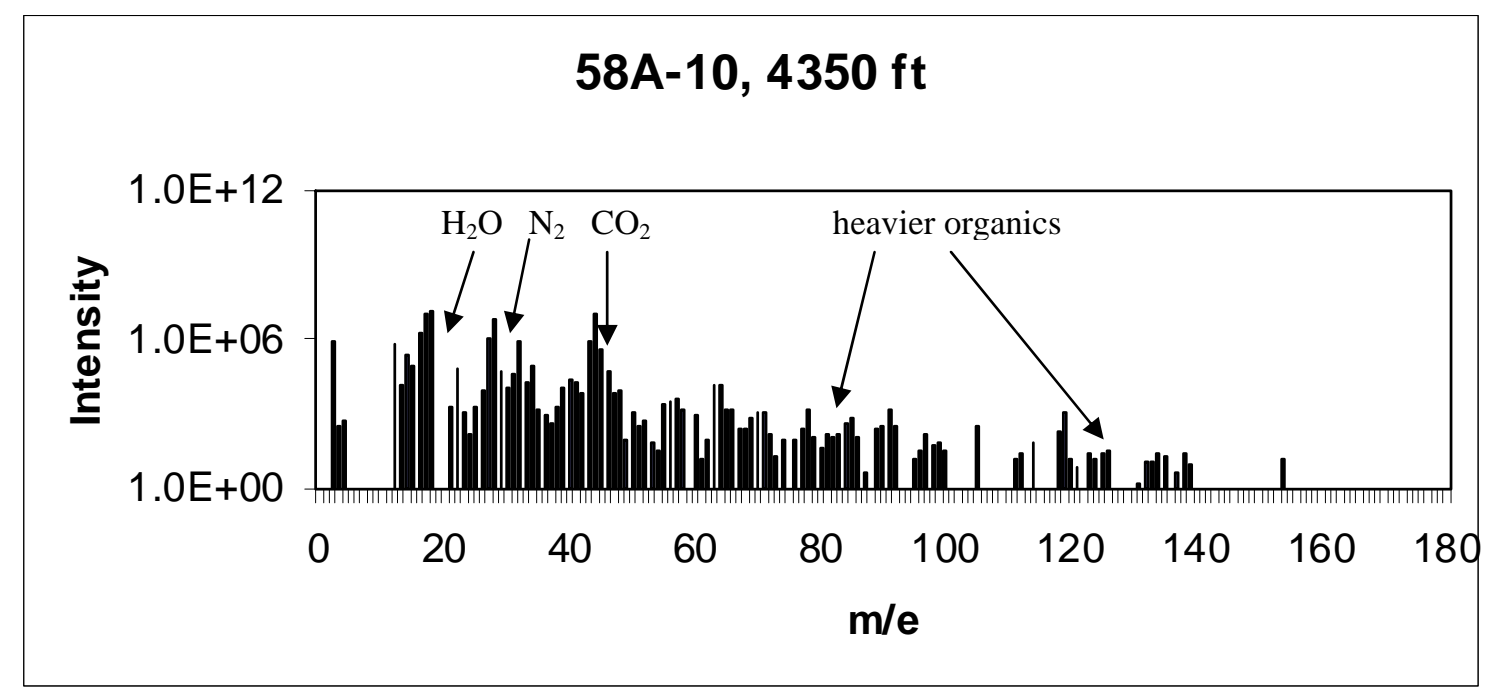

Figure 1: Typical FIT mass spectra of fluid inclusions in drill chips from a particular depth.

Due to the extensive amount of data (mass peaks from 2 to 180 for each of the over 2000 samples), data processing is required and a tool is needed to display the data. In order for FIS analyses to be useful and economically applied to the geothermal industry an approach similar to FIT was adopted. The Rockware ${ }^{\circledR}$ program Logger was selected for plotting the mass spectra. Logger produces graphic strip logs from user-created or imported data files. The raw data was plotted using the standard format for FIS (Norman et al., 2005).

\subsection{Fracture Identification}

Fracture identification was conducted using drilling logs from geologists and drillers for each well and identification from the cores. Evidence of fractures was varied and included: visual evidence in photos, mud losses in drilling logs, or notes of fractures, veins, and vein-filling minerals in core logs. Fractures were identified as 'open' if mud losses or visual evidence of openness were noted, and size (small/medium/large) if possible by observed size, amount of vein mineral present, or amount of mud loss. Closed fractures were identified where significant calcite, quartz, or pyrite, was noted in logs.

\subsection{Statistical Analysis}

We evaluated basic statistics for each well and each chemical species. These statistics include average, standard deviation, maximum and minimum for fracture and non-fracture locations.

A statistical analysis performed on the data from the wells was focused on evaluating predictive chemical species that may be used to identify fractured or permeable zones in future well development. The Analysis of Variance (ANOVA) was used to evaluate the correlation between datasets of zones considered fractured and not fractured. The hypothesis tested here was whether there is a statistical difference in concentrations of chemical species between the 
fractured and non-fractured zones. This is important because it can lead to an understanding of which chemical species have different concentrations in these zones, which allows for prediction of fracture zones in future wells. In these statistical evaluations the sample size for these two zones was generally greater than 100 . A systematic removal of outliers was not performed in this analysis in order to increase the effectiveness of this method for predicting fracture zones in future wells.

StatistiXL Version 1.8 was used to perform the ANOVA statistical analysis. The program assumes equal treatment of variances using the general linear model (GLM). The evaluation is that the data relationship has a probability greater than the F-distribution ( $\mathrm{Pr}>\mathrm{F})$. If this probability value is less than 0.05 there is statistical significance between at least one of the datasets compared to others within a 95 percent confidence interval (Kuehl 2000). 


\subsection{DATA}

Two different relationships were developed from the data: spatial relationship and a statistical relationship. Plotting the more common geothermal gases, fractures and vein locations indicate a spatial relationship between the location of veins, fractures, and peaks in concentration of several geothermal gases. The statistical relationship is indicated by the difference in average concentrations for select species in fracture and non-fracture zones. Also based on the ANOVA analysis the data indicated a significant difference in concentrations of select species between fracture and non-fracture zones in a number of wells.

\subsection{Spatial Relationship}

\subsubsection{Steamboat Springs Well 87-29}

Figure 2 presents a FIS log with fractures for Well 87-29 from Steamboat Springs, Nevada. The primary production zone for this well is from about 500 to about 1,200 feet with the hottest temperatures from about 600 to 850 feet. In the primary production zone from 500 to 1,200 feet there is a broad zone of fractures with maximum size of 10 to 100 millimeters and a few with larger openings. It can be seen that several of the peaks that occur in the FIS data corresponds to fracture openings. Peaks at 250, 825, 950, 1100, 2200, 3100, 3225, and 3700 feet correspond to open fractures. The deeper fractures are thinner and are cooler according to the temperature survey. 


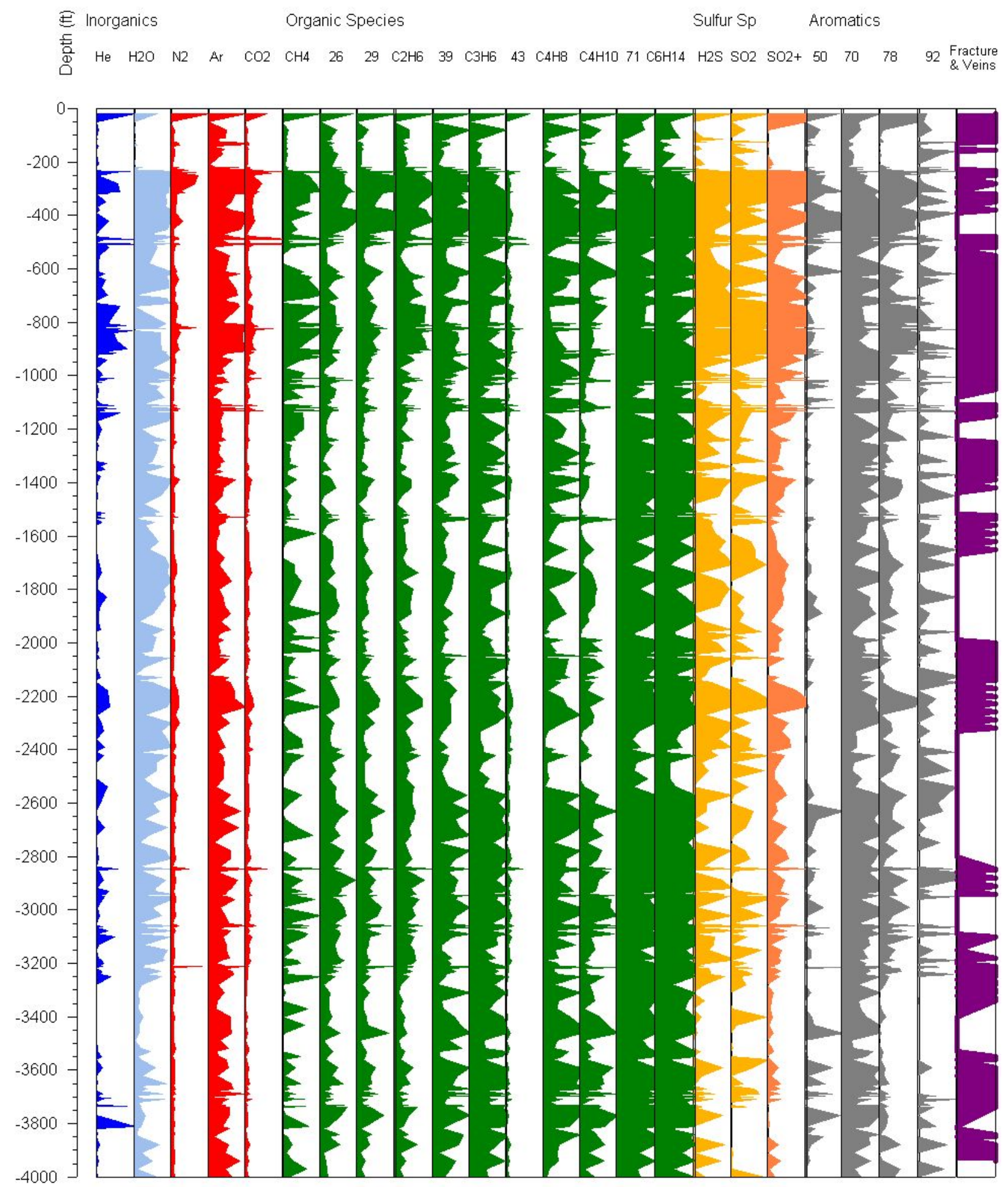

Figure 2: FIS Log for Steamboat Springs Well 87-29. 
There are broader less defined peaks (some species not having peaks) on the FIS log that do not appear to correspond to open fractures such as 450, 2650, and 3800 feet. These broader peaks may correspond to older, closed fractures or alteration mineral assemblages. In several of these zones, 2650, and 3800 feet, the $\mathrm{CO}_{2}$ and several of the heavier organic species appear to have low values. The fractures below 3000 feet have peaks in a number of the organic compounds and aromatics but low values of $\mathrm{H}_{2} \mathrm{O}, \mathrm{CO}_{2}, \mathrm{~N}_{2}$, and Ar. These fractures are not in the production zone.

\subsubsection{Karaha Well T2}

Figure 3 presents the FIS log with fracture locations for Karaha Well T-2. There are less fracture zones than in Steamboat Springs well. The vapor zone in this well begins at about 3,000 feet. The change from meteoric water to a vapor zone is suggested by the change in the concentrations of the heavier organic species at about 3,200 feet. On the FIS log the heavier organic species are shown in green. Water, $\mathrm{H}_{2} \mathrm{O}$ also occurs at about 2900 feet to 3,650 feet suggesting a transition at this depth. Significant fractures occur associated with peaks across numerous chemical species including at 2,500,2,900,3,200, and at 4,300 feet. There are also a couple of fracture locations that are not associated with peaks in any chemical species such as 3,750, 3,900 and 4,100 feet. However there are smaller peaks at approximately 3,950 feet which maybe due to the fracture at 3,900 and/or 4,100 feet.

A vapor zone was encountered in this well below about $3000 \mathrm{ft}$. and temperatures increase dramatically below $2200 \mathrm{ft}$, suggesting the fractures encountered are associated with the geothermal system and are open and active. From the FIS log Figure 3, below $3600 \mathrm{ft}$, many of the species do not have peaks at fracture locations including heavier organics, He, aromatics and $\mathrm{H}_{2} \mathrm{O}$. This suggests that in vapor-dominated systems it is the total gas concentration particularly $\mathrm{CO}_{2}, \mathrm{~N}_{2}$ and $\mathrm{Ar}$ and to a lesser extent the sulfur species and $\mathrm{CH}_{4}$ that indicate open, active fractures. 


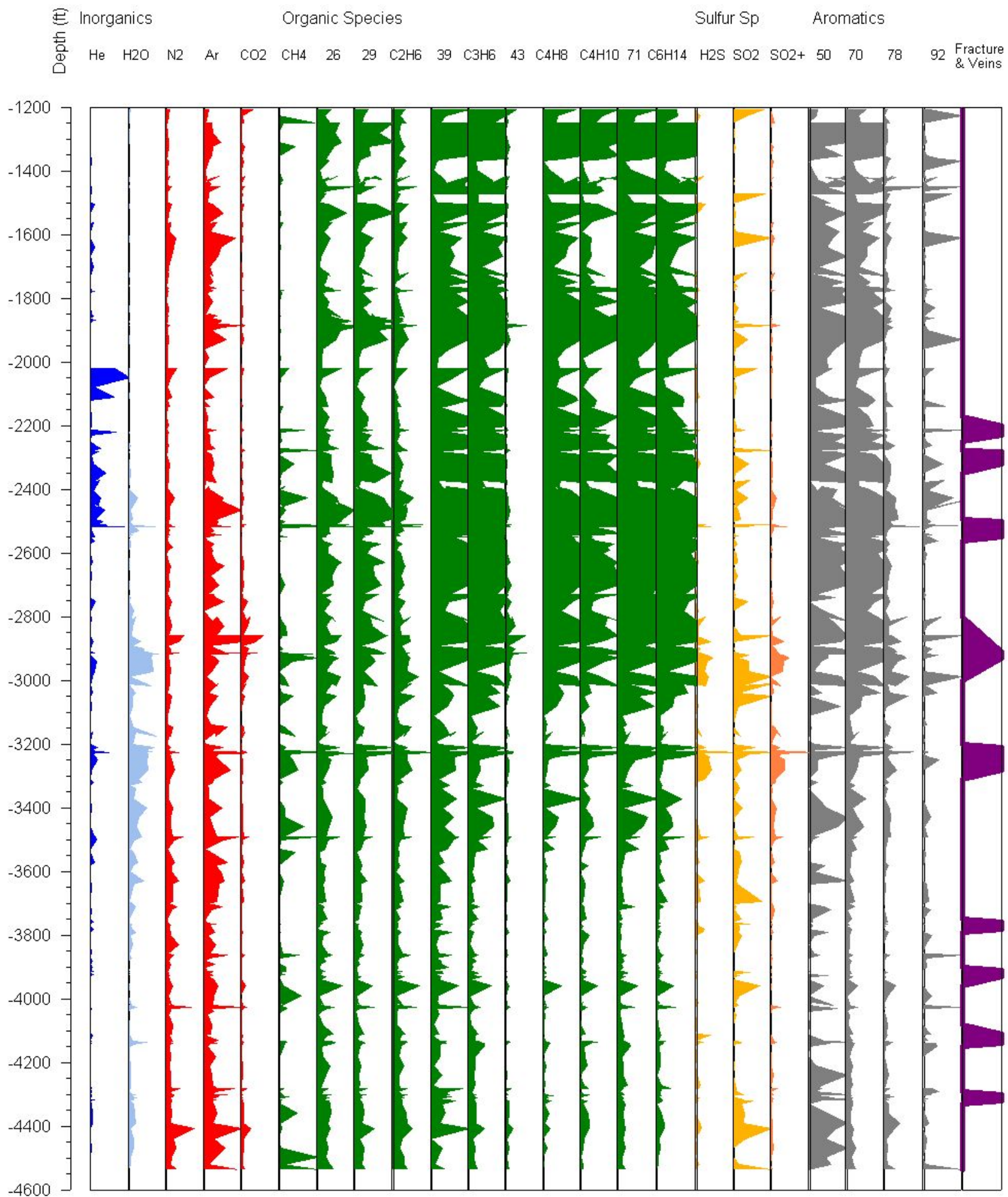

Figure 3: FIS Log for Karaha Well T-2. A vapor zone begins at approximately 3000 feet in the well. 


\subsubsection{Karaha Well K-21}

Figure 4 presents the FIS log with fracture locations for Karaha Well K-21. Well K-21 is a liquid dominated well with little to no steam zone. The rock types encountered in Well K-21 are a series of tuffs and lava flows. Predominant veining material is calcite with some anhydrite after about 4,100 foot depth. Wairakite also occurs after about 4,800 feet.

The major fluid inclusion gas boundary is the occurrence of $\mathrm{H}_{2} \mathrm{O}$ at approximately 3,700 feet and another occurrence of $\mathrm{H}_{2} \mathrm{O}$ at 4,800 feet. At 4,800 feet there is also an increase in the concentration of a number of the organic species and the aromatic species. This level roughly corresponds to the illite alteration zone as defined in Moore, et al., 2008 and the introduction of wairakite.

Distinct peaks in a number of chemical species occur at 1,700 ft, 2,275 ft, 4,225 ft, 4,400 ft, and 4,900 ft. These distinct peaks occur where fractures/veins are noted. The peaks are primarily in the organic species (shown in green) and the sulfur species (shown in yellow/orange). In addition where water (light blue) does occur, peaks are associated with fracture locations. High concentrations in argon (second red column) correspond almost every time with fracture locations. Notable exceptions occur at 1,800 feet with a distinct fracture location and little to no peak concentrations in any of the plotted species. This also occurs in the zone from about 4,420 to 4,600 feet. In this zone however there are peaks in the sulfur species and argon concentrations. These two areas consist of broken, brownish color lava flows with minor calcite veining. 


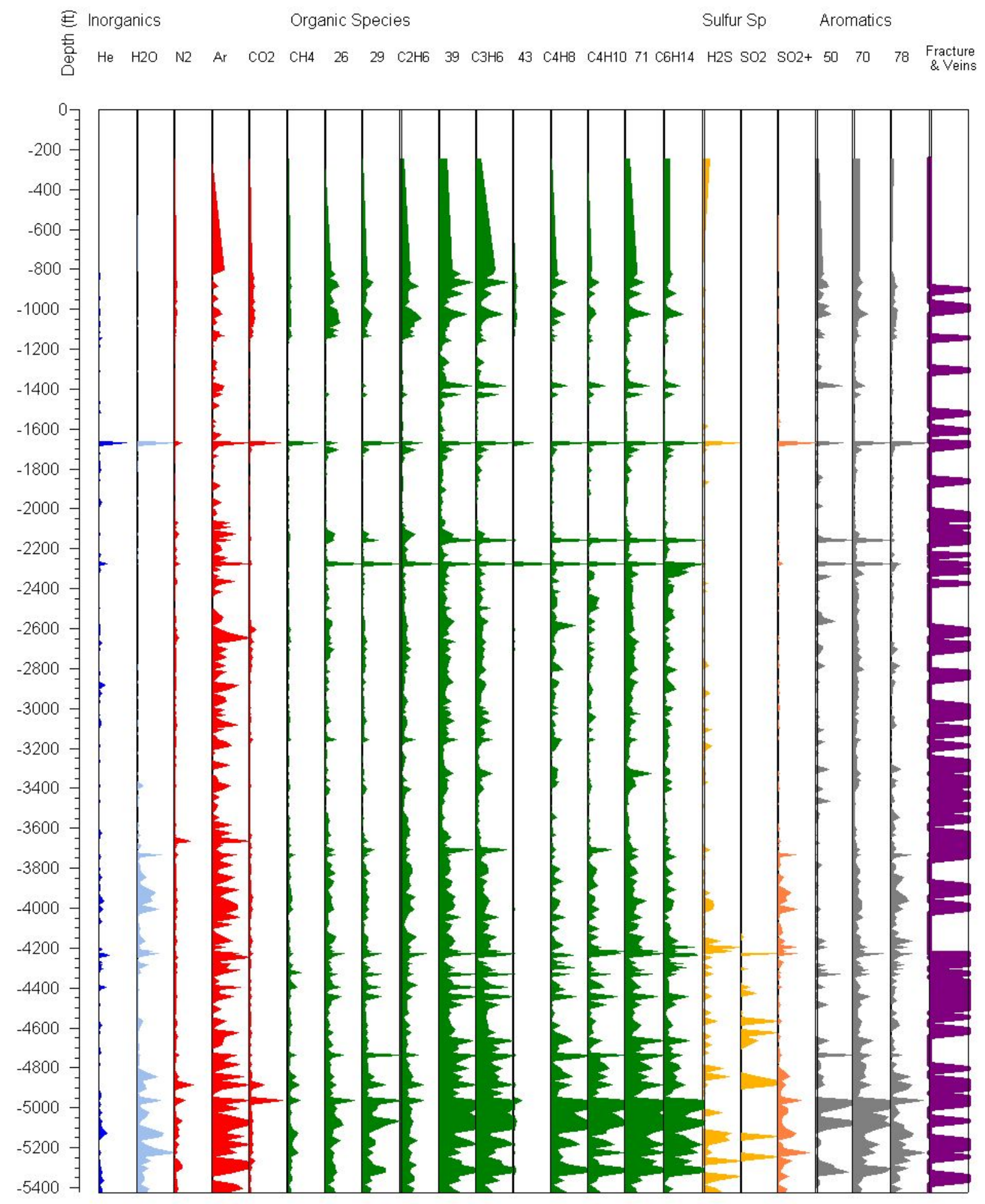

Figure 4: FIS Log for Karaha Well K-21. 


\subsubsection{Karaha Well K-33}

Figure 5 presents the FIS log with fracture locations for Karaha Well K-33. The well encountered primarily lava flows some minor tuffs. Several fault zones were encountered including one at about 3,898 to 3,916 feet and again at about 4,272 to 4,282 feet. These fault zones correspond to the occurrence of $\mathrm{H}_{2} \mathrm{O}$ in the fluid inclusion gas analysis. There is a significant increase in the concentration of $\mathrm{H}_{2} \mathrm{O}$ after about 4,400 feet. This corresponds to an increase in open cavities noted in the core log. Below about 6,200 feet there is also noted an increase in porosity and altered zones. The FIS log indicates a large increase in a number of gas concentrations from about 6,300 feet to the bottom of the well.

There are numerous fractures and veins in Well K-33 as compared to Well T-2. A number of the fractures correspond to increase concentrations in several of the gas species including argon, the organic species (shown in green), the sulfur species (shown in yellow) and the aromatics (shown in grey). Once $\mathrm{H}_{2} \mathrm{O}$ does occur there are multiple peaks in the concentration that correspond with increase concentrations in the other species and to fractures. The majority of fractures are calcite and quartz filled with some pyrite veining.

There are several zones where fractures do not occur. There is a lack of calcite veins from 5,177 feet to 5,419 feet however quartz veins do occur. In this zone there are peaks in several species concentrations but not necessarily in all of them and not consistently in most of the species at the same depth. Again from approximately 5,575 feet to 5,775 there is a general lack of peaks in the species concentration and there is a general lack of calcite and quartz veins in this zone. 
E Inorganics

Organic Species

Sulfur Sp Aromatics

$\begin{array}{lllllllllllllllllllllllll}\text { 言 } & \mathrm{He} & \mathrm{H} 2 \mathrm{O} & \mathrm{N} 2 & \mathrm{Ar} & \mathrm{CO} 2 & \mathrm{CH} 4 & 26 & 29 & \mathrm{C} 2 \mathrm{H} 6 & 39 & \mathrm{C} 3 \mathrm{H} 6 & 43 & \mathrm{C} 4 \mathrm{H} 8 & \mathrm{C} 4 \mathrm{H} 10 & 71 & \mathrm{C} 6 \mathrm{H} 14 & \mathrm{H} 2 \mathrm{~S} & \mathrm{SO} 2 & \mathrm{SO} 2+ & 50 & 70 & 78 & \text { Fracture } \\ \text { \& Veins }\end{array}$

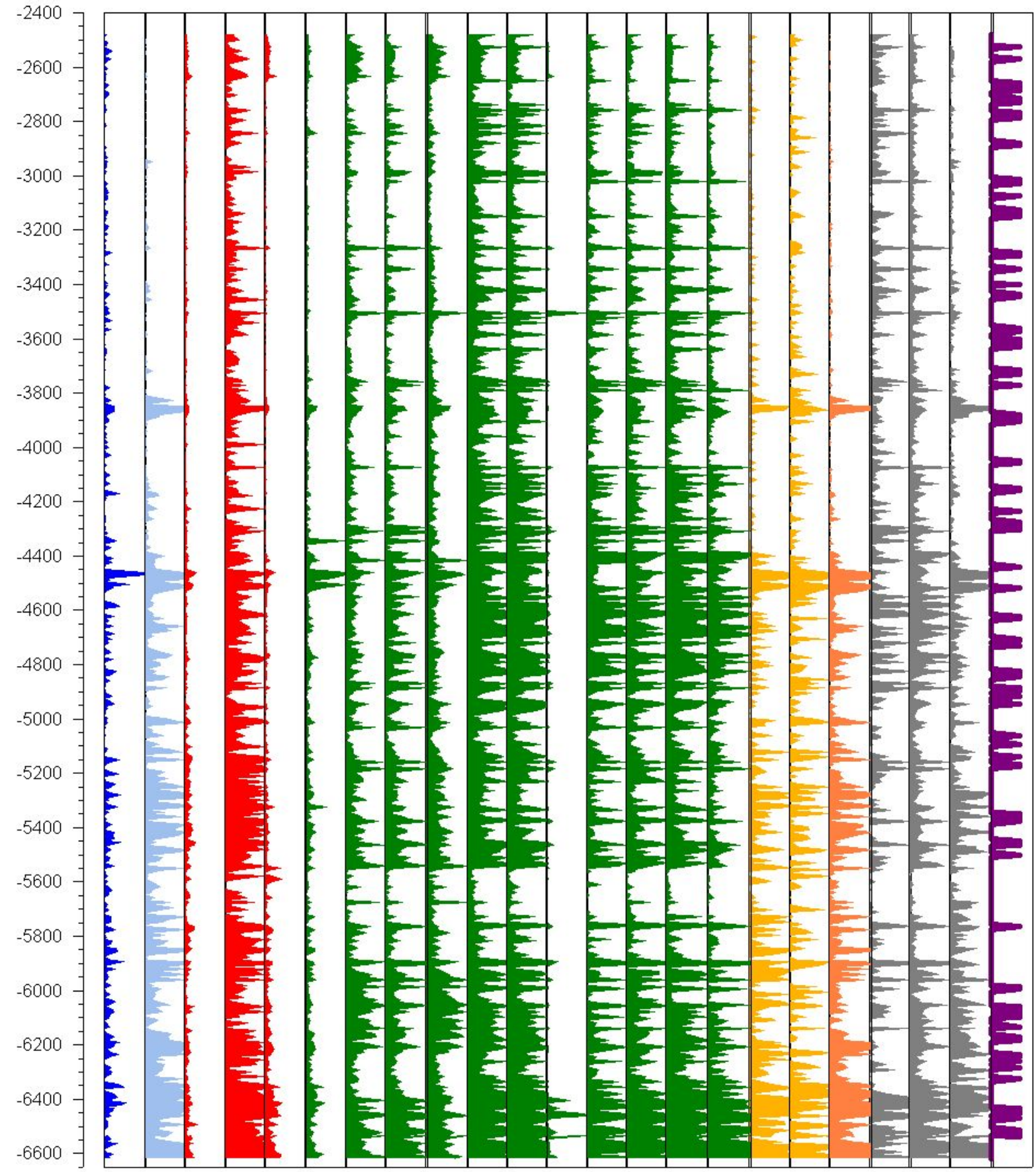

Figure 5: FIS Log for Karaha Well K-33. 


\subsubsection{Glass Mountain Well GMF 17 A-6}

Figure 6 presents the FIS log for Glass Mountain Well GMF 17A-6. This well did not have core but was sampled from well chips. There is limited information that was available for fracture/vein locations. This well consists of a sequence of interlayered volcanic, contact metamorphic, and granodioritic intrusive rocks. Alteration zoning is well-developed and ranges from zeolite-smectitie to argillic to propylitic alteration with increasing depth. Temperature data for this well indicates that the well was not drilled in an area of upwelling and boiling.

The occurrence of $\mathrm{H}_{2} \mathrm{O}$ fluid inclusion concentration appears to correspond to the occurrence of dacite/rhyolite dikes in the upper parts of the well and to the occurrence of granodiorite starting at approximately 7,656 feet to the bottom of the well. Peak concentrations in argon, several organic species, sulfur and benzene (78) occur in conjunction with the occurrence of the more felsic volcanics and with fracture locations. Fracture locations are based on the occurrence of calcite and quartz veins as well as pyrite. Calcite veining was common from approximately 3,500 feet to 4,640 feet. Calcite veining did not occur after about 6,780 feet. Quartz veining was abundant from approximately 5,160 feet to 8,400 feet. Thin siliceous tuff layers were encountered in the granodiorite and are shown in the fracture column in Figure 6.

Breaks in the fracture/vein locations appear to correspond to areas where the fluid inclusion gas concentrations are low for several species. Peaks in the gas concentrations occur with the fracture/vein locations particularly from about 3,300 feet to 3,570 feet and 6,100 feet to 6,900 feet. 


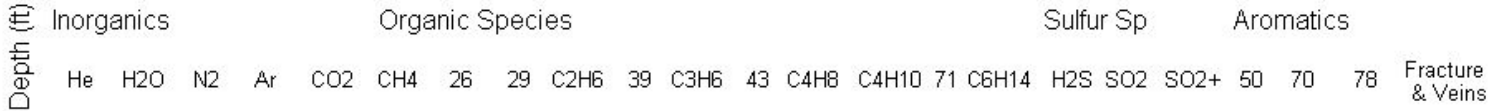

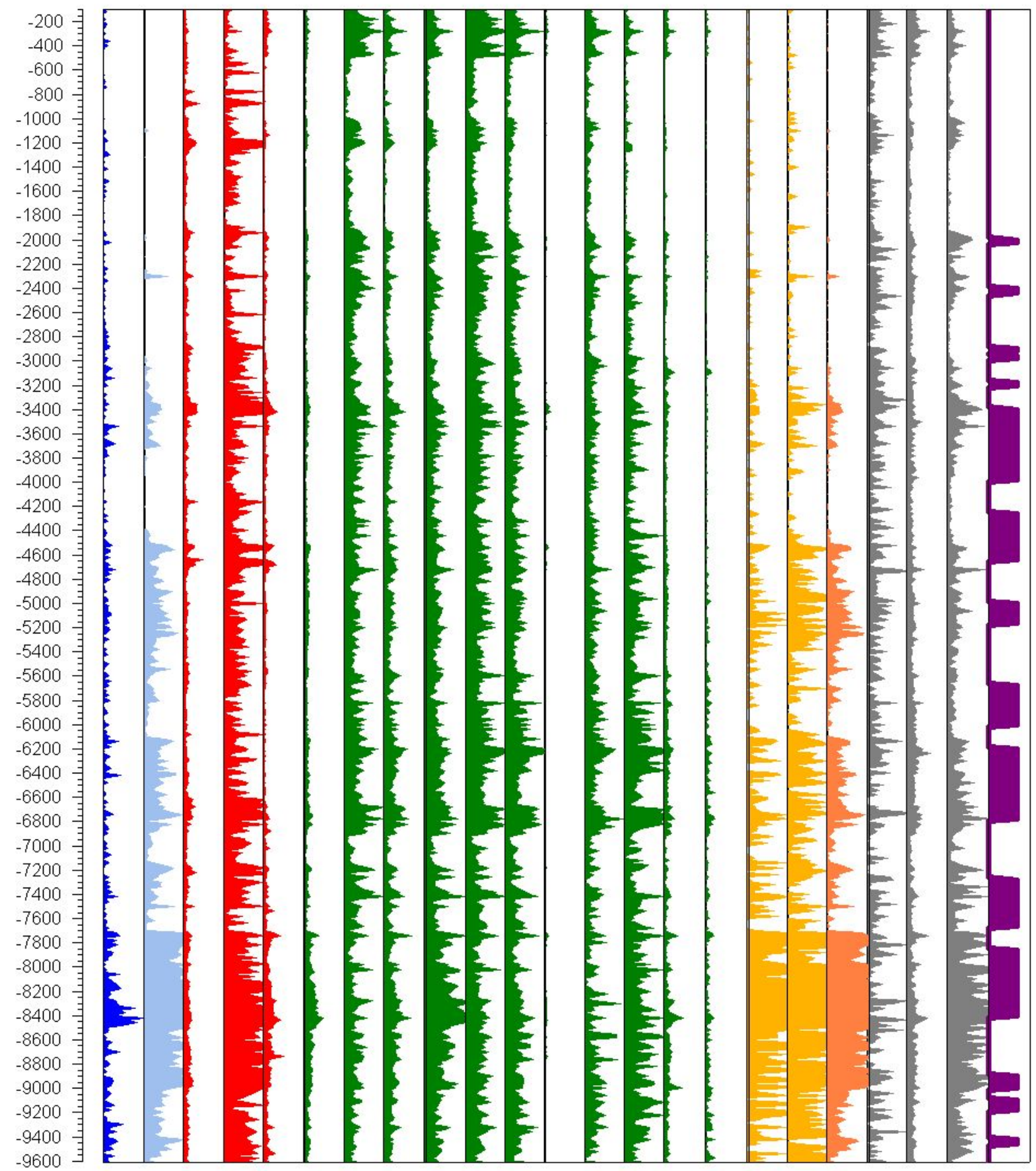

Figure 6: FIS Log for Glass Mountain Well GMF 17A-6. 


\subsubsection{Glass Mountain Well 88-28}

Figure 7 presents the FIS log with fractures for Glass Mountain Well 88-28. Many of the fracture zones correspond to numerous peaks in the chemical species. The one fracture zone that appears not to have corresponding peaks is at a depth of about 2,900 feet however there are a number of peaks in the organic species at approximately 3,000 feet. This may correspond to the fracture location at 2,900 feet. There are several areas where peaks in the chemical species are evident however there is not a corresponding fracture location. This occurs as a broad peak from about 750 to 850 feet and again near the bottom of the well from 3,250 to 3,350 feet. There is also a change in the chemical signature starting at about 1,600 feet. Water, $\mathrm{H}_{2} \mathrm{O}$ occurs and to a lesser degree the sulfur species. The organic species have lower concentrations until about 3,000 feet. 


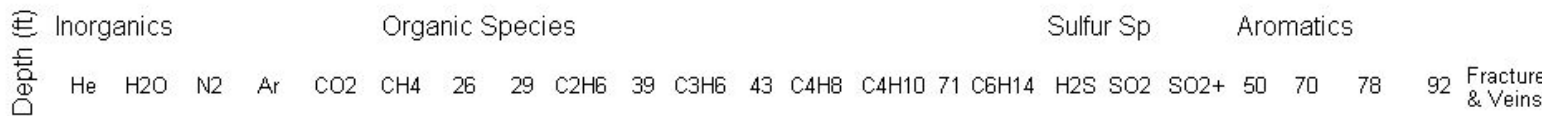

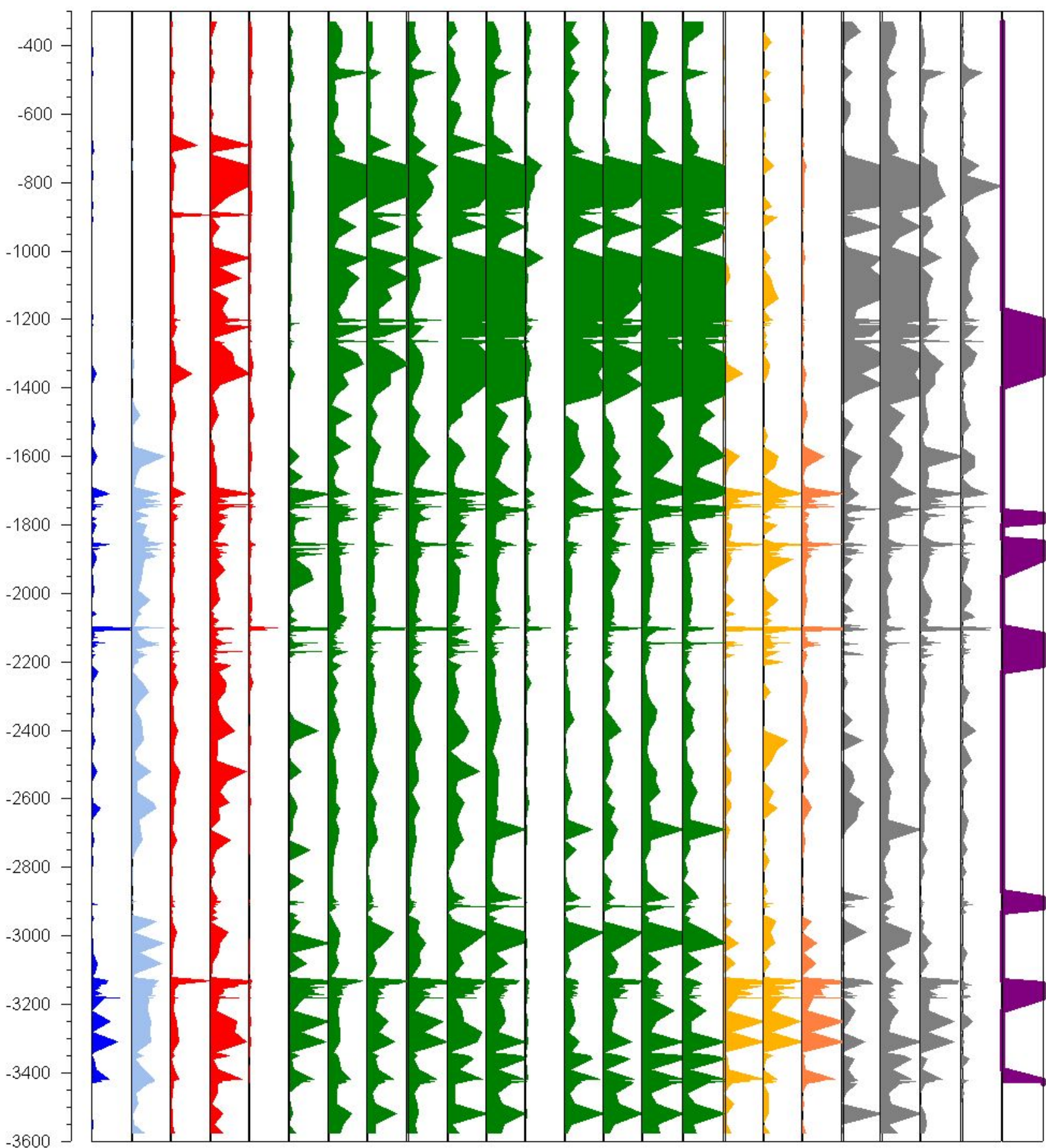

Figure 7: FIS Log for Glass Mountain Well 88-28. 


\subsection{Statistical Relationship}

\subsubsection{Basic Statistics}

Basic statistics were calculated for each of the chemical species in each of the wells. This included the maximum, minimum, average, and standard deviation. The fracture and non-fracture zones were delineated and the maximum, minimum, average, and standard deviation for select species were calculated. This is presented in Table 2.

Table 2: Basic statistics per well for fracture and non-fracture areas for select species.

\begin{tabular}{|c|c|c|c|c|c|c|}
\hline \multicolumn{2}{|c|}{$\begin{array}{c}\text { Steamboat Springs } \\
\text { Well } 87-29\end{array}$} & $\begin{array}{c}16 \\
\mathrm{CH} 4\end{array}$ & $\begin{array}{c}18 \\
\mathrm{H} 2 \mathrm{O} \\
\end{array}$ & $\begin{array}{c}28 \\
\mathrm{~N} 2 / \mathrm{CO} \\
\end{array}$ & $\begin{array}{c}34 \\
\mathrm{H} 2 \mathrm{~S} \\
\end{array}$ & $\begin{array}{c}44 \\
\mathrm{CO} 2\end{array}$ \\
\hline \multirow[t]{6}{*}{ Fracture } & & & & & & \\
\hline & Maximum & $1.24 \mathrm{E}+07$ & $2.06 \mathrm{E}+07$ & $7.54 \mathrm{E}+06$ & $9.01 E+05$ & $2.91 E+07$ \\
\hline & Minimum & $0.00 E+00$ & $0.00 E+00$ & $1.66 \mathrm{E}+05$ & $0.00 E+00$ & $5.73 E+05$ \\
\hline & Average & $1.63 E+06$ & $7.71 E+06$ & $1.44 \mathrm{E}+06$ & $8.77 E+04$ & $4.18 E+06$ \\
\hline & $\begin{array}{l}\text { Std Dev } \\
\text { Avg + Std }\end{array}$ & $2.13 E+06$ & $5.23 E+06$ & $1.40 \mathrm{E}+06$ & $1.39 E+05$ & $4.91 E+06$ \\
\hline & Dev & $3.76 E+06$ & $1.29 E+07$ & $2.84 \mathrm{E}+06$ & $2.27 E+05$ & $9.09 E+06$ \\
\hline \multirow[t]{6}{*}{$\begin{array}{l}\text { No } \\
\text { Fracture }\end{array}$} & & & & & & \\
\hline & Maximum & $3.62 E+07$ & $1.60 \mathrm{E}+07$ & $1.31 \mathrm{E}+07$ & $4.67 E+05$ & $2.08 \mathrm{E}+07$ \\
\hline & Minimum & $0.00 E+00$ & $0.00 E+00$ & $0.00 \mathrm{E}+00$ & $0.00 E+00$ & $0.00 E+00$ \\
\hline & Average & $1.21 \mathrm{E}+06$ & $7.59 E+06$ & $1.23 \mathrm{E}+06$ & $4.74 \mathrm{E}+04$ & $2.96 E+06$ \\
\hline & $\begin{array}{l}\text { Std Dev } \\
\text { Avg + Std }\end{array}$ & $2.97 E+06$ & $4.99 \mathrm{E}+06$ & $1.20 \mathrm{E}+06$ & $7.22 \mathrm{E}+04$ & $2.44 E+06$ \\
\hline & Dev & $4.19 E+06$ & $1.26 \mathrm{E}+07$ & $2.43 E+06$ & $1.20 \mathrm{E}+05$ & $5.40 E+06$ \\
\hline
\end{tabular}

\begin{tabular}{|c|c|c|c|c|c|c|}
\hline \multicolumn{2}{|c|}{ Well T-2 } & $\begin{array}{c}16 \\
\mathrm{CH} 4\end{array}$ & $\begin{array}{c}18 \\
\mathrm{H} 2 \mathrm{O}\end{array}$ & $\begin{array}{c}28 \\
\mathrm{~N} 2 / \mathrm{CO}\end{array}$ & $\begin{array}{c}34 \\
\mathrm{H} 2 \mathrm{~S}\end{array}$ & $\begin{array}{c}44 \\
\mathrm{CO} 2\end{array}$ \\
\hline \multirow[t]{6}{*}{ Fracture } & & & & & & \\
\hline & Maximum & $5.50 \mathrm{E}+06$ & $1.04 \mathrm{E}+07$ & $7.59 E+06$ & $2.33 E+04$ & $7.26 E+06$ \\
\hline & Minimum & $0.00 E+00$ & $0.00 E+00$ & $1.32 E+05$ & $0.00 \mathrm{E}+00$ & $3.53 E+05$ \\
\hline & Average & $3.87 E+05$ & $1.37 E+06$ & $1.07 E+06$ & $2.48 \mathrm{E}+03$ & 1.17E+06 \\
\hline & $\begin{array}{l}\text { Std Dev } \\
\text { Avg + Std }\end{array}$ & $8.49 E+05$ & $2.27 E+06$ & $9.52 E+05$ & $4.32 \mathrm{E}+03$ & $9.98 \mathrm{E}+05$ \\
\hline & Dev & $1.24 \mathrm{E}+06$ & $3.64 \mathrm{E}+06$ & $2.02 E+06$ & $6.79 E+03$ & $2.17 E+06$ \\
\hline \multirow[t]{2}{*}{$\begin{array}{l}\text { No } \\
\text { Fracture }\end{array}$} & & & & & & \\
\hline & Maximum & $5.08 \mathrm{E}+06$ & $1.14 \mathrm{E}+07$ & $4.99 E+06$ & $6.10 E+04$ & $1.34 \mathrm{E}+07$ \\
\hline
\end{tabular}




\begin{tabular}{|l|l|l|l|l|l|} 
Minimum & $0.00 \mathrm{E}+00$ & $0.00 \mathrm{E}+00$ & $2.99 \mathrm{E}+05$ & $0.00 \mathrm{E}+00$ & $3.25 \mathrm{E}+05$ \\
$\begin{array}{l}\text { Average } \\
\begin{array}{l}\text { Std Dev } \\
\text { Avg + Std } \\
\text { Dev }\end{array}\end{array}$ & $4.42 \mathrm{E}+05$ & $1.81 \mathrm{E}+06$ & $1.28 \mathrm{E}+06$ & $4.42 \mathrm{E}+03$ & $1.68 \mathrm{E}+06$ \\
& $1.38 \mathrm{E}+06$ & $2.64 \mathrm{E}+06$ & $8.92 \mathrm{E}+05$ & $8.71 \mathrm{E}+03$ & $2.00 \mathrm{E}+06$ \\
\end{tabular}

\begin{tabular}{|c|c|c|c|c|c|c|}
\hline \multicolumn{2}{|c|}{$\begin{array}{c}\text { Karaha } \\
\text { Well K-21 }\end{array}$} & $\begin{array}{c}16 \\
\mathrm{CH} 4\end{array}$ & $\begin{array}{c}18 \\
\mathrm{H} 2 \mathrm{O}\end{array}$ & $\begin{array}{c}28 \\
\mathrm{~N} 2 / \mathrm{CO}\end{array}$ & $\begin{array}{c}34 \\
\mathrm{H} 2 \mathrm{~S}\end{array}$ & $\begin{array}{c}44 \\
\mathrm{CO} 2\end{array}$ \\
\hline \multirow{6}{*}{ Fracture } & & & & & & \\
\hline & Maximum & $2.27 E+06$ & $1.46 \mathrm{E}+07$ & $5.23 E+06$ & $2.07 E+05$ & $1.97 E+07$ \\
\hline & Minimum & $6.95 E+04$ & $6.49 E+04$ & $5.81 E+04$ & $0.00 E+00$ & $3.45 E+05$ \\
\hline & Average & $2.29 E+05$ & $1.05 E+06$ & $5.29 \mathrm{E}+05$ & $5.27 \mathrm{E}+03$ & $1.59 \mathrm{E}+06$ \\
\hline & $\begin{array}{l}\text { Std Dev } \\
\text { Avg + Std }\end{array}$ & $2.64 \mathrm{E}+05$ & $2.13 E+06$ & $7.35 E+05$ & $2.11 \mathrm{E}+04$ & $2.65 E+06$ \\
\hline & Dev & $4.93 E+05$ & $3.18 \mathrm{E}+06$ & $1.26 \mathrm{E}+06$ & $2.64 \mathrm{E}+04$ & $4.24 \mathrm{E}+06$ \\
\hline \multirow[t]{6}{*}{$\begin{array}{l}\text { No } \\
\text { Fracture }\end{array}$} & & & & & & \\
\hline & Maximum & $8.39 E+05$ & $1.49 \mathrm{E}+07$ & $2.20 \mathrm{E}+06$ & $5.24 \mathrm{E}+04$ & $3.90 E+06$ \\
\hline & Minimum & $4.54 \mathrm{E}+04$ & $2.39 E+04$ & $0.00 \mathrm{E}+00$ & $0.00 E+00$ & $3.36 \mathrm{E}+05$ \\
\hline & Average & $1.77 E+05$ & $9.30 \mathrm{E}+05$ & $4.32 E+05$ & $2.99 \mathrm{E}+03$ & $1.18 \mathrm{E}+06$ \\
\hline & $\begin{array}{l}\text { Std Dev } \\
\text { Avg + Std }\end{array}$ & $1.30 \mathrm{E}+05$ & $2.06 \mathrm{E}+06$ & $3.46 \mathrm{E}+05$ & $7.43 E+03$ & $7.96 \mathrm{E}+05$ \\
\hline & Dev & $3.07 E+05$ & $2.99 \mathrm{E}+06$ & $7.78 \mathrm{E}+05$ & $1.04 \mathrm{E}+04$ & $1.98 \mathrm{E}+06$ \\
\hline
\end{tabular}

\begin{tabular}{|c|c|c|c|c|c|c|}
\hline \multicolumn{2}{|c|}{$\begin{array}{c}\text { Karaha } \\
\text { Well K-33 }\end{array}$} & $\begin{array}{c}16 \\
\mathrm{CH} 4\end{array}$ & $\begin{array}{c}18 \\
\mathrm{H} 2 \mathrm{O}\end{array}$ & $\begin{array}{c}28 \\
\mathrm{~N} 2 / \mathrm{CO}\end{array}$ & $\begin{array}{c}34 \\
\mathrm{H} 2 \mathrm{~S}\end{array}$ & $\begin{array}{c}44 \\
\mathrm{CO} 2\end{array}$ \\
\hline \multirow{6}{*}{ Fracture } & & & & & & \\
\hline & Maximum & $1.22 \mathrm{E}+06$ & $2.12 \mathrm{E}+07$ & $2.81 \mathrm{E}+06$ & $1.32 \mathrm{E}+05$ & $7.19 E+06$ \\
\hline & Minimum & $3.41 E+04$ & $3.48 \mathrm{E}+03$ & $0.00 \mathrm{E}+00$ & $0.00 \mathrm{E}+00$ & $2.25 E+05$ \\
\hline & Average & $2.33 E+05$ & $2.59 E+06$ & $5.65 E+05$ & $9.62 E+03$ & $1.47 E+06$ \\
\hline & $\begin{array}{l}\text { Std Dev } \\
\text { Avg + Std }\end{array}$ & $1.75 E+05$ & $4.43 E+06$ & $5.45 E+05$ & $2.03 E+04$ & $1.48 \mathrm{E}+06$ \\
\hline & Dev & $4.09 E+05$ & $7.01 E+06$ & $1.11 \mathrm{E}+06$ & $3.00 E+04$ & $2.95 \mathrm{E}+06$ \\
\hline \multirow[t]{6}{*}{$\begin{array}{l}\text { No } \\
\text { Fracture }\end{array}$} & & & & & & \\
\hline & Maximum & $5.17 \mathrm{E}+06$ & $2.43 E+07$ & $3.16 \mathrm{E}+06$ & $3.57 E+05$ & $9.89 E+06$ \\
\hline & Minimum & $4.88 \mathrm{E}+04$ & $2.96 \mathrm{E}+04$ & $0.00 \mathrm{E}+00$ & $0.00 \mathrm{E}+00$ & $0.00 E+00$ \\
\hline & Average & $3.49 E+05$ & $4.79 E+06$ & $6.93 \mathrm{E}+05$ & $2.10 \mathrm{E}+04$ & $1.77 \mathrm{E}+06$ \\
\hline & $\begin{array}{l}\text { Std Dev } \\
\text { Avg + Std }\end{array}$ & 4.37E+05 & $6.60 \mathrm{E}+06$ & $5.43 \mathrm{E}+05$ & 4.67E+04 & 1.77E+06 \\
\hline & Dev & $7.86 \mathrm{E}+05$ & $1.14 \mathrm{E}+07$ & $1.24 \mathrm{E}+06$ & $6.77 \mathrm{E}+04$ & $3.54 \mathrm{E}+06$ \\
\hline
\end{tabular}




\begin{tabular}{|c|c|c|c|c|c|c|}
\hline \multicolumn{2}{|c|}{$\begin{array}{c}\text { Glass Mountain } \\
\text { Well 88-28 }\end{array}$} & $\begin{array}{c}16 \\
\mathrm{CH} 4\end{array}$ & $\begin{array}{c}18 \\
\mathrm{H} 2 \mathrm{O}\end{array}$ & $\begin{array}{c}28 \\
\mathrm{~N} 2 / \mathrm{CO}\end{array}$ & $\begin{array}{c}34 \\
\mathrm{H} 2 \mathrm{~S}\end{array}$ & $\begin{array}{c}44 \\
\mathrm{CO} 2\end{array}$ \\
\hline \multirow{6}{*}{ Fracture } & & & & & & \\
\hline & Maximum & $5.43 E+06$ & $1.19 \mathrm{E}+07$ & $5.51 \mathrm{E}+06$ & $5.90 \mathrm{E}+05$ & $1.64 \mathrm{E}+07$ \\
\hline & Minimum & $0.00 \mathrm{E}+00$ & $0.00 \mathrm{E}+00$ & $1.82 \mathrm{E}+05$ & $0.00 \mathrm{E}+00$ & $2.23 E+05$ \\
\hline & Average & $7.75 E+05$ & $3.84 \mathrm{E}+06$ & $9.75 \mathrm{E}+05$ & $2.37 E+04$ & $1.35 E+06$ \\
\hline & $\begin{array}{l}\text { Std Dev } \\
\text { Avg + Std }\end{array}$ & $1.10 \mathrm{E}+06$ & $3.40 E+06$ & $6.56 \mathrm{E}+05$ & $7.79 \mathrm{E}+04$ & $1.98 \mathrm{E}+06$ \\
\hline & Dev & $1.88 \mathrm{E}+06$ & $7.24 \mathrm{E}+06$ & $1.63 \mathrm{E}+06$ & $1.02 \mathrm{E}+05$ & $3.34 E+06$ \\
\hline \multicolumn{7}{|l|}{$\begin{array}{l}\text { No } \\
\text { Fracture }\end{array}$} \\
\hline & Maximum & $4.62 E+06$ & $1.20 \mathrm{E}+07$ & $1.48 \mathrm{E}+07$ & $1.07 \mathrm{E}+05$ & $3.67 E+06$ \\
\hline & Minimum & $0.00 \mathrm{E}+00$ & $0.00 \mathrm{E}+00$ & $1.68 \mathrm{E}+05$ & $0.00 \mathrm{E}+00$ & $2.41 E+05$ \\
\hline & Average & $4.85 E+05$ & $2.52 E+06$ & $1.06 \mathrm{E}+06$ & $7.28 \mathrm{E}+03$ & $1.11 \mathrm{E}+06$ \\
\hline & $\begin{array}{l}\text { Std Dev } \\
\text { Avg + Std }\end{array}$ & $8.59 \mathrm{E}+05$ & $3.14 \mathrm{E}+06$ & $1.94 \mathrm{E}+06$ & $1.71 \mathrm{E}+04$ & $6.66 \mathrm{E}+05$ \\
\hline & Dev & $1.34 \mathrm{E}+06$ & $5.66 \mathrm{E}+06$ & $2.99 \mathrm{E}+06$ & $2.43 \mathrm{E}+04$ & $1.78 \mathrm{E}+06$ \\
\hline
\end{tabular}

\begin{tabular}{|c|c|c|c|c|c|c|}
\hline \multicolumn{2}{|c|}{$\begin{array}{c}\text { Glass Mountain } \\
\text { Well } 17 A-6\end{array}$} & $\begin{array}{c}16 \\
\mathrm{CH} 4\end{array}$ & $\begin{array}{c}18 \\
\mathrm{H} 2 \mathrm{O}\end{array}$ & $\begin{array}{c}28 \\
\mathrm{~N} 2 / \mathrm{CO}\end{array}$ & $\begin{array}{c}34 \\
\mathrm{H} 2 \mathrm{~S}\end{array}$ & $\begin{array}{c}44 \\
\mathrm{CO} 2\end{array}$ \\
\hline \multirow[t]{6}{*}{ Fracture } & & & & & & \\
\hline & Maximum & $6.02 E+05$ & $1.36 \mathrm{E}+07$ & $4.80 \mathrm{E}+06$ & $7.58 \mathrm{E}+04$ & $7.65 E+06$ \\
\hline & Minimum & $6.46 \mathrm{E}+04$ & $0.00 \mathrm{E}+00$ & $2.32 \mathrm{E}+05$ & $0.00 E+00$ & 4.07E+05 \\
\hline & Average & $2.21 \mathrm{E}+05$ & $2.69 E+06$ & $9.73 E+05$ & $8.01 E+03$ & $1.57 E+06$ \\
\hline & $\begin{array}{l}\text { Std Dev } \\
\text { Avg + Std }\end{array}$ & $1.01 \mathrm{E}+05$ & $3.20 \mathrm{E}+06$ & $7.03 E+05$ & $1.21 \mathrm{E}+04$ & $1.06 \mathrm{E}+06$ \\
\hline & Dev & $3.22 \mathrm{E}+05$ & $5.90 \mathrm{E}+06$ & $1.68 \mathrm{E}+06$ & $2.01 E+04$ & $2.63 E+06$ \\
\hline \multirow[t]{6}{*}{$\begin{array}{l}\text { No } \\
\text { Fracture }\end{array}$} & & & & & & \\
\hline & Maximum & $1.32 \mathrm{E}+06$ & $2.02 E+07$ & $4.09 E+06$ & $4.47 E+05$ & $1.15 E+07$ \\
\hline & Minimum & $7.67 E+04$ & $9.68 \mathrm{E}+03$ & $1.94 \mathrm{E}+05$ & $0.00 E+00$ & $4.65 E+05$ \\
\hline & Average & $3.24 E+05$ & $5.38 E+06$ & $1.13 \mathrm{E}+06$ & $3.27 E+04$ & $2.46 \mathrm{E}+06$ \\
\hline & $\begin{array}{l}\text { Std Dev } \\
\text { Avg + Std }\end{array}$ & $2.09 \mathrm{E}+05$ & $6.15 E+06$ & $5.80 \mathrm{E}+05$ & $6.30 E+04$ & $1.70 \mathrm{E}+06$ \\
\hline & Dev & $5.33 E+05$ & $1.15 E+07$ & $1.71 \mathrm{E}+06$ & $9.57 E+04$ & $4.16 \mathrm{E}+06$ \\
\hline
\end{tabular}




\subsubsection{ANOVA Analysis}

There are two distinct sets of data that have been included in this analysis. The fractured zones were selected either by visual observation of the cores or by lost circulation zones in well logs. The mean for the fracture zones versus the non-fracture zones were compared for each of the chemical species of interest. Graphical representation of this method is presented in Figure 8.

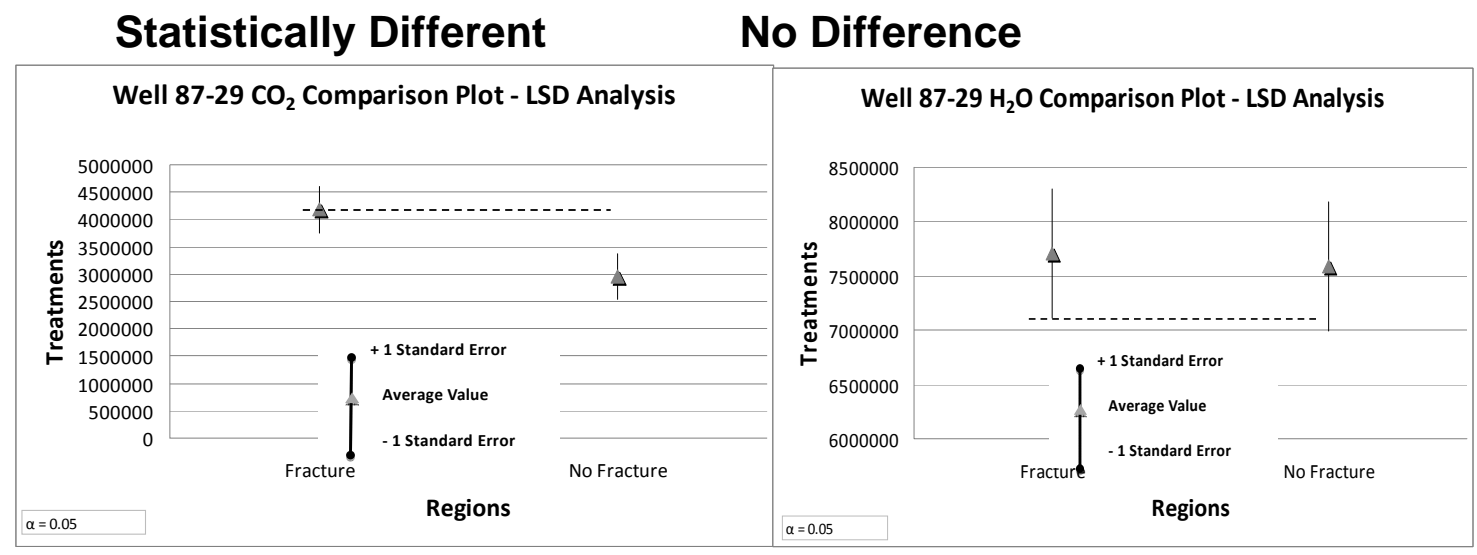

Figure 8: Comparison of means for fracture and non-fracture areas for select chemical species for Well 87-29. For $\mathrm{CO}_{2}$ there is a statistical difference between fracture and non-fracture areas however for $\mathrm{H}_{2} \mathrm{O}$ there is not a statistical difference.

The results of the ANOVA evaluation are presented in Table 3. In Wells 87-29, K33, T2, and 88-28 the Pr>F statistic shows values less than 0.05 using the GLM procedure (highlighted in yellow). This provides the initial insight that one set of data (fractured zones) is statistically different from the other (non-fractured zones) because the value obtained is less than 0.05 (confidence interval of 95 percent). The chemical species that have a difference with a confidence interval of 95 percent are $\mathrm{H}_{2}, \mathrm{He}, \mathrm{H}_{2} \mathrm{~S}$, and Mass 64. Well K-21 has different chemical species that indicate fracture zones versus non-fracture zones including $\mathrm{H} 2, \mathrm{CH}_{4}$ (mass 16), and masses 70, 85 and 92 where are the aromatics.

For $\mathrm{CO}_{2}$ the $\mathrm{Pr}>\mathrm{F}$ statistical value is less than 0.21 for all wells indicating that there is a 79 percent confidence interval. The highest value occurs in Well 88-28 whereas for Wells 87-29 and T2, the Pr>F statistical value is less than 0.05 and less than 0.108 for the other two wells. Calcite occurs in a number of these wells and typically only in the fracture zones and therefore the higher concentrations of $\mathrm{CO}_{2}$ in fracture areas appears to be related to the occurrence of calcite. Water $\left(\mathrm{H}_{2} \mathrm{O}\right)$ only has a Pr>F value less than 0.05 for Wells K33 and 88-28. This may be due to the ubiquitous nature of water in the wells. 
Table 3: Summary of ANOVA Statistics for five wells.

Summary ANOVA Statistics

\begin{tabular}{|c|c|c|c|c|c|}
\hline \multirow[b]{2}{*}{ Component } & \multicolumn{5}{|c|}{ Well (Pr>F) } \\
\hline & $\begin{array}{c}\text { Well } \\
87-29\end{array}$ & K33 & $\mathrm{T} 2$ & K21 & $\begin{array}{l}\text { Well } \\
88-28\end{array}$ \\
\hline $\mathrm{H} 2$ & 0.008 & 0.001 & 0.021 & 0.346 & 0.010 \\
\hline 3 & 0.047 & 0.470 & 0.015 & 0.080 & 0.011 \\
\hline 4 & 0.350 & 0.197 & 0.147 & & 0.006 \\
\hline $\mathrm{CH} 4$ & 0.670 & 0.069 & 0.214 & 0.077 & 0.292 \\
\hline 16 & 0.186 & 0.008 & 0.629 & 0.031 & 0.026 \\
\hline $\mathrm{H} 2 \mathrm{O}$ & 0.839 & 0.001 & 0.155 & 0.655 & 0.002 \\
\hline 26 & 0.505 & 0.925 & 0.867 & 0.170 & 0.367 \\
\hline $\mathrm{N} 2 / \mathrm{CO}$ & 0.155 & 0.033 & 0.073 & 0.140 & 0.664 \\
\hline 29 & 0.454 & 0.497 & 0.999 & 0.122 & 0.697 \\
\hline 30 & 0.128 & 0.069 & 0.095 & 0.154 & 0.016 \\
\hline $\mathrm{H} 2 \mathrm{~S}$ & 0.001 & 0.015 & 0.018 & 0.201 & 0.025 \\
\hline 39 & 0.955 & 0.189 & 0.285 & 0.180 & 0.296 \\
\hline $\mathrm{Ar}$ & 0.064 & 0.811 & 0.438 & 0.102 & 0.209 \\
\hline 41 & 0.921 & 0.134 & 0.561 & 0.182 & 0.354 \\
\hline 43 & 0.016 & 0.212 & 0.119 & 0.164 & 0.444 \\
\hline $\mathrm{CO} 2$ & 0.004 & 0.108 & 0.008 & 0.064 & 0.212 \\
\hline 48 & 0.000 & 0.058 & 0.199 & 0.818 & 0.010 \\
\hline 50 & 0.996 & 0.157 & 0.559 & 0.190 & 0.346 \\
\hline 56 & 0.749 & 0.130 & 0.866 & 0.173 & 0.372 \\
\hline 58 & 0.494 & 0.243 & 0.277 & 0.181 & 0.506 \\
\hline 64 & 0.000 & 0.021 & 0.032 & 0.326 & 0.004 \\
\hline 70 & 0.938 & 0.344 & 0.244 & 0.047 & 0.385 \\
\hline 71 & 0.994 & 0.193 & 0.326 & 0.095 & 0.327 \\
\hline 78 & 0.088 & 0.350 & 0.034 & 0.232 & 0.063 \\
\hline 85 & 0.946 & 0.399 & 0.169 & 0.036 & 0.375 \\
\hline 92 & 0.137 & 0.386 & 0.781 & 0.008 & 0.937 \\
\hline
\end{tabular}

$\operatorname{Pr}>\mathrm{F}<0.05$

$\operatorname{Pr}>\mathrm{F}<0.10$

$\operatorname{Pr}>\mathrm{F}<0.15$ 


\subsection{Mineral Assemblages}

Mineral assemblages that occurred in veins and fractures were identified in order to determine if there were corresponding peaks in the fluid inclusion gas data. Figures 9 through 11 present photographs of some of the minerals and their occurrences in the core samples.

Massive calcite occurs as fracture infilling and as veins in Steamboat Springs Well 87-29 as seen in Figure 9. Stibnite (antimony sulfide) also occurs as an infilling mineral (Jones 1912). Peaks in the concentration of $\mathrm{CO}_{2}$ correspond with fracture locations particularly in the production zone. Peaks in the concentration of the sulfur species also correspond with the fracture locations particularly in the production zone and to a lesser degree in the non-production zone.
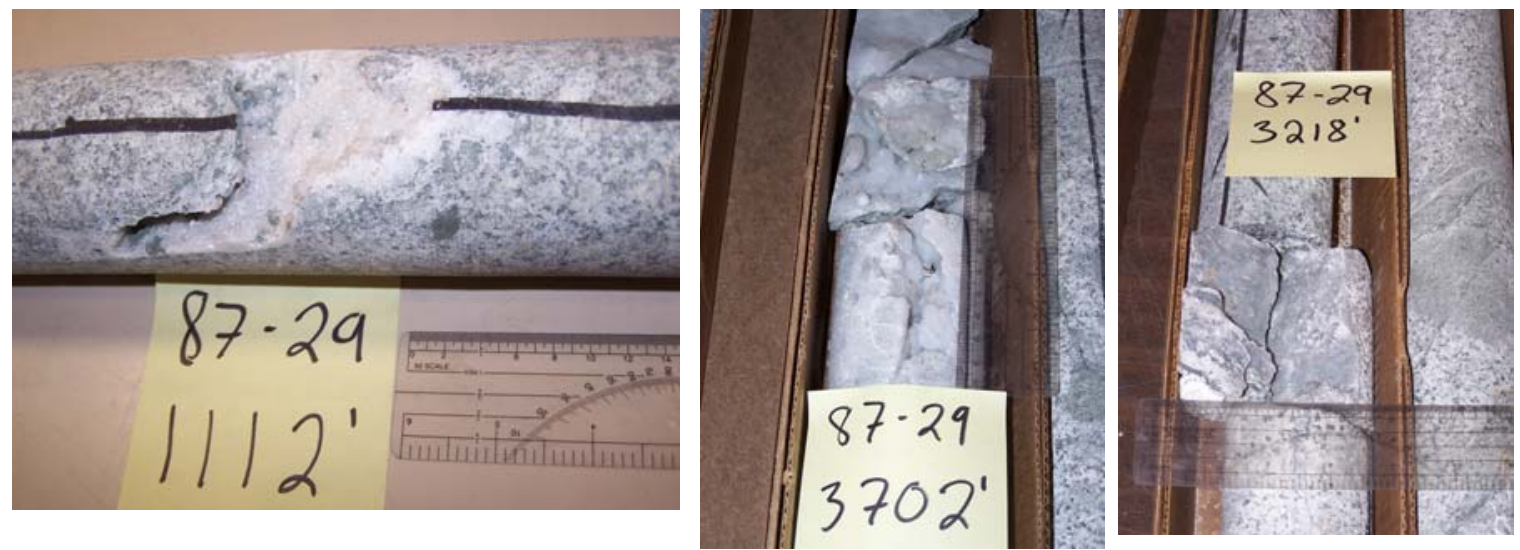

Figure 9: Photographs of the occurrence of calcite and quartz in Steamboat Springs Well 87-29.

Vein minerals in Well T-2 included pyrite, and calcite as seen in Figure 10. The fracture noted at 2,500 feet is associated with several pyrite veins. Multiple peaks are common also in the fracture starting at about 2,850 feet. Fractures and veins with pyrite and calcite occur in this zone as well. Peaks in the concentration of $\mathrm{H}_{2} \mathrm{~S}$ tend to occur where pyrite is noted. The FIS log in Figure 3 indicates that in the concentration of $\mathrm{CO}_{2}$ and the organics were higher from 2800 to 3000 feet than in the lower zone. Calcite is not as prevalent a secondary mineral in the lower zone than in the 2800 to $3000 \mathrm{ft}$. range. $\mathrm{N}_{2}$, $\mathrm{Ar}$, and the lighter hydrocarbons also had similar concentrations in the lower zone to the upper zone, except for the extremely sharp increase in $\mathrm{N}_{2}$ at $2880 \mathrm{ft}$. From the logs there does not appear to be a major change in rock or secondary minerals at this depth. At $2919 \mathrm{ft}$. there is an open partially pyrite filled, fracture is the only notable change on 
the log. From 3900 to $4200 \mathrm{ft}$. there is little $\mathrm{H}_{2} \mathrm{O}$ but several total gas peaks that correlate with fractures. The gas peaks correspond to zones with multiple veins filled with pyrite and quartz; chlorite alteration is throughout the rock.
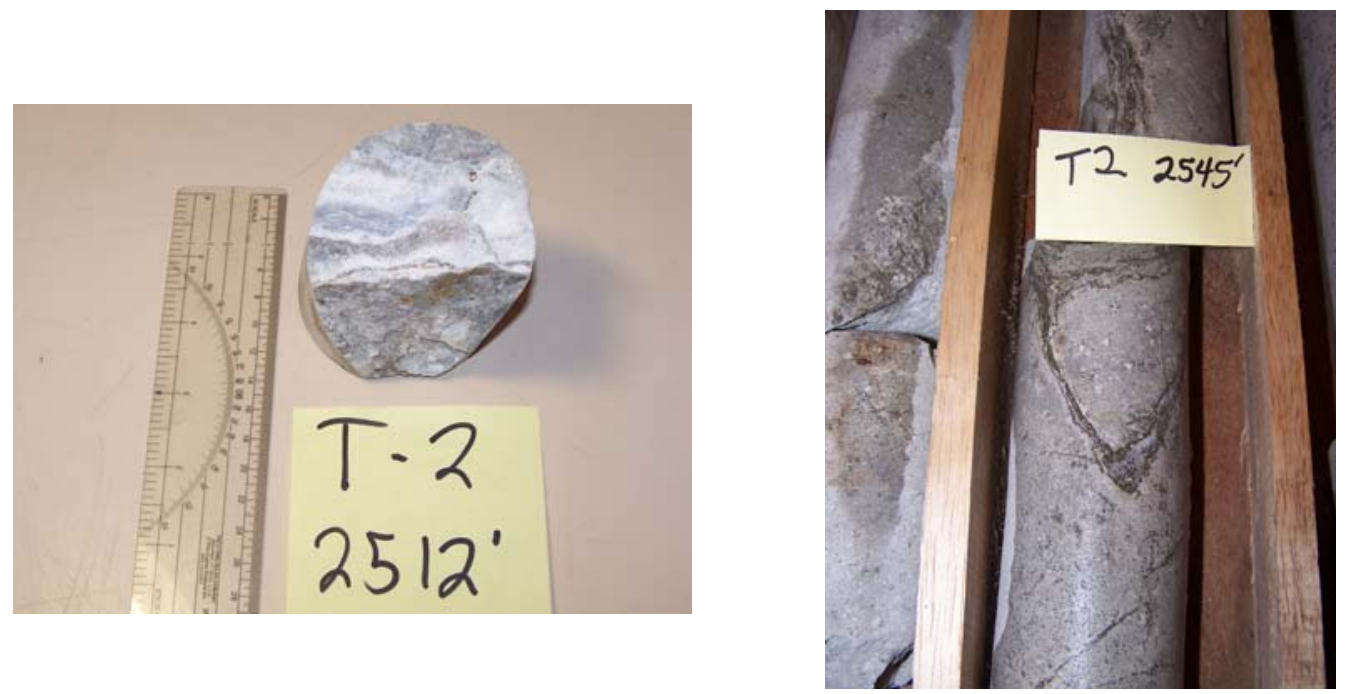

Figure 10: Photographs of the occurrence of pyrite in Karaha Well T-2.

The fractures in Glass Mountain Well 88-28 from about 1,750 to 1,900 feet are associated with small veins and fractures containing bladed calcite. The peaks in FIS data from about 2,900 feet to 3,150 feet and again the broad peaks from 3,250 to 3,350 feet correspond to areas of observed hydrothermal breccia veins. The concentration of $\mathrm{CO}_{2}$ is very low in these areas and is probably due to the release of $\mathrm{CO}_{2}$ with steam during hydrofracturing.

This well is composed of mixed volcanics and felsic volcanics. The mixed volcanics are series of highly altered basalts to about 1266 feet. At this depth to 1722 feet are white to red tuffs with some layers of sandy sediments. Below 1722 feet are the felsic volcanics. A static water level in the well occurred at approximately 1500 feet and the static temperature increased drastically at this depth according to the geology logs. As seen in Figure 7 this is also the depth (1500 to 1700 feet) where the $\mathrm{H}_{2} \mathrm{O}$ concentration increases and becomes significant. The other gases also have peaks at the 1700 foot depth. The $\mathrm{H}_{2} \mathrm{O}$ concentration increase from about 3000 feet to 3400 feet. This is a zone of a matrix of basalt but numerous calcite veins, some open vugs, and small bladed calcite. Just above this zone from 2890 to 2920 feet, is a series of fractures about $1 / 4$ inch thick spaced at about 1 to 2 feet for about 20 feet in length. These fractures are infilled with calcite. The concentration of $\mathrm{H}_{2} \mathrm{O}$ in this zone is near zero, suggesting that these are older fractures as oppose to the zone from 3000 to 3400 feet. 
Although it is unknown what the production zone is in this well, the hottest temperatures in the well according to the geological records are from approximately 2900 feet to 3300 feet. There are two peaks at $1600 \mathrm{ft}$. and $1700 \mathrm{ft}$. that do not correspond to a fracture, vein or vug. At this depth the rock was a tuff that had amygdules and veins filled with quartz and calcite. The peak at 2100 is a fracture containing bladed calcite. The next set of large peaks is at 3100 to $3400 \mathrm{ft}$. From $1700 \mathrm{ft}$. to $3400 \mathrm{ft}$. the total gas concentration is primarily $\mathrm{He}, \mathrm{H}_{2} \mathrm{O} \mathrm{N}, \mathrm{Ar}, \mathrm{CO}_{2}, \mathrm{CH}_{4}$, lighter organics and the sulfur species. The heavier organics are lacking.
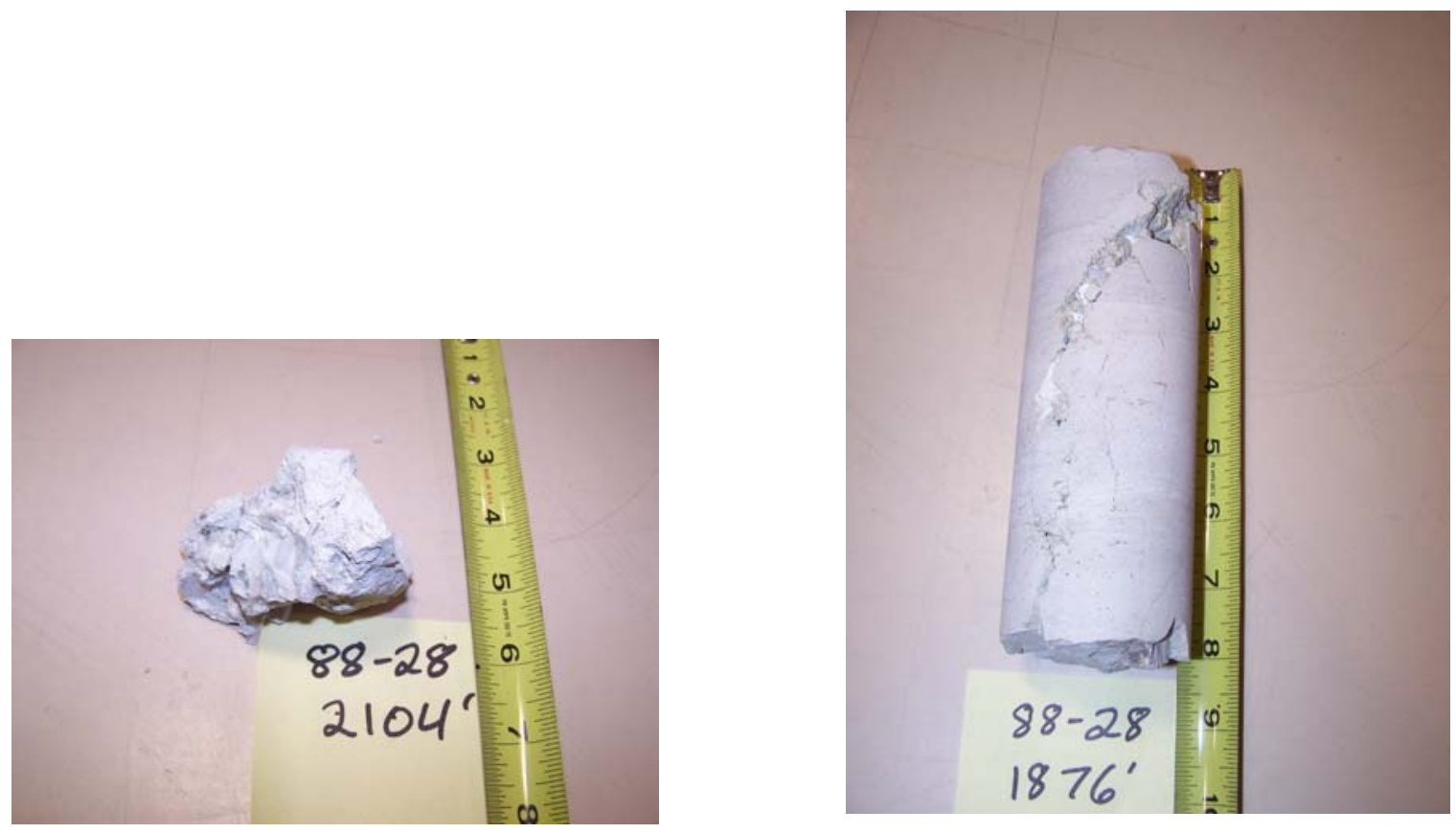

Figure 11: Photographs of calcite occurrence in Glass Mountain Well 88-28.

\section{4. $\mathrm{CO}_{2} / \mathrm{N}_{2}$ Ratio and Permeability}

The $\mathrm{CO}_{2} / \mathrm{N}_{2}$ ratio versus total gas plot illustrates boiling and condensation trends (Norman et al, 2002). Gas partition coefficients for $\mathrm{CO}_{2}$ and $\mathrm{N}_{2}$ are considerably different. As steam separates from liquid during boiling gases such as $\mathrm{H}_{2}, \mathrm{~N}_{2}$ and $\mathrm{CH}_{4}$ preferentially move into the vapor phase and the more soluble gases $\mathrm{CO}_{2}$ and $\mathrm{H}_{2} \mathrm{~S}$ stay partially in liquid phase. Nitrogen $\left(\mathrm{N}_{2}\right)$ would move into the vapor phase creating a higher ratio with less gas. Condensation would increase both gaseous species concentration and total gas would increase. Figure 12 presents how boiling and condensation would plot on a $\mathrm{CO}_{2} / \mathrm{N}_{2}$ versus $\%$ total gas. 


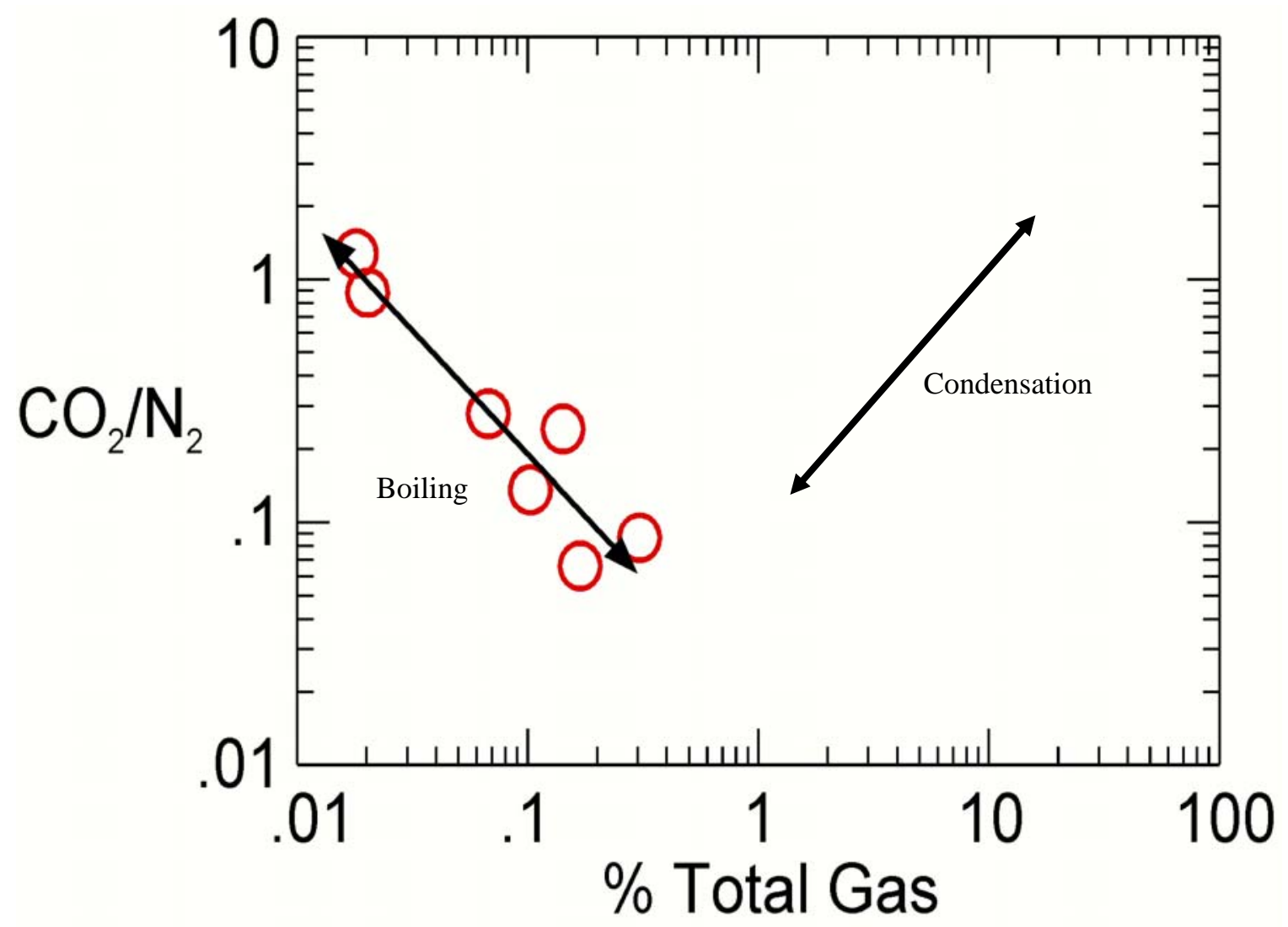

Figure 12: $\mathrm{CO}_{2} / \mathrm{N}_{2}$ ratio versus percent total gas plots. Trends for boiling and condensation.

The idea is can this change in the ratio of $\mathrm{CO}_{2} / \mathrm{N}_{2}$ be used to indicate fracture zones. As a fracture opens, pressure would drop and boiling would occur. As boiling occurs $\mathrm{N}_{2}$ would move into the vapor phase and there would be a change in the ratio. The change in ratio was plotted with lost circulation, felsic dikes and altered zones for a number of Coso wells. Coso wells had well logs available that indicated lost circulation zones, felsic dikes, and altered zones. Figure 13 presents a plot of Coso Well 68-20. The peaks indicate the largest changes in the $\mathrm{CO} 2$ / N2 ratio. 


\section{Coso Well 68-20 Permeability}

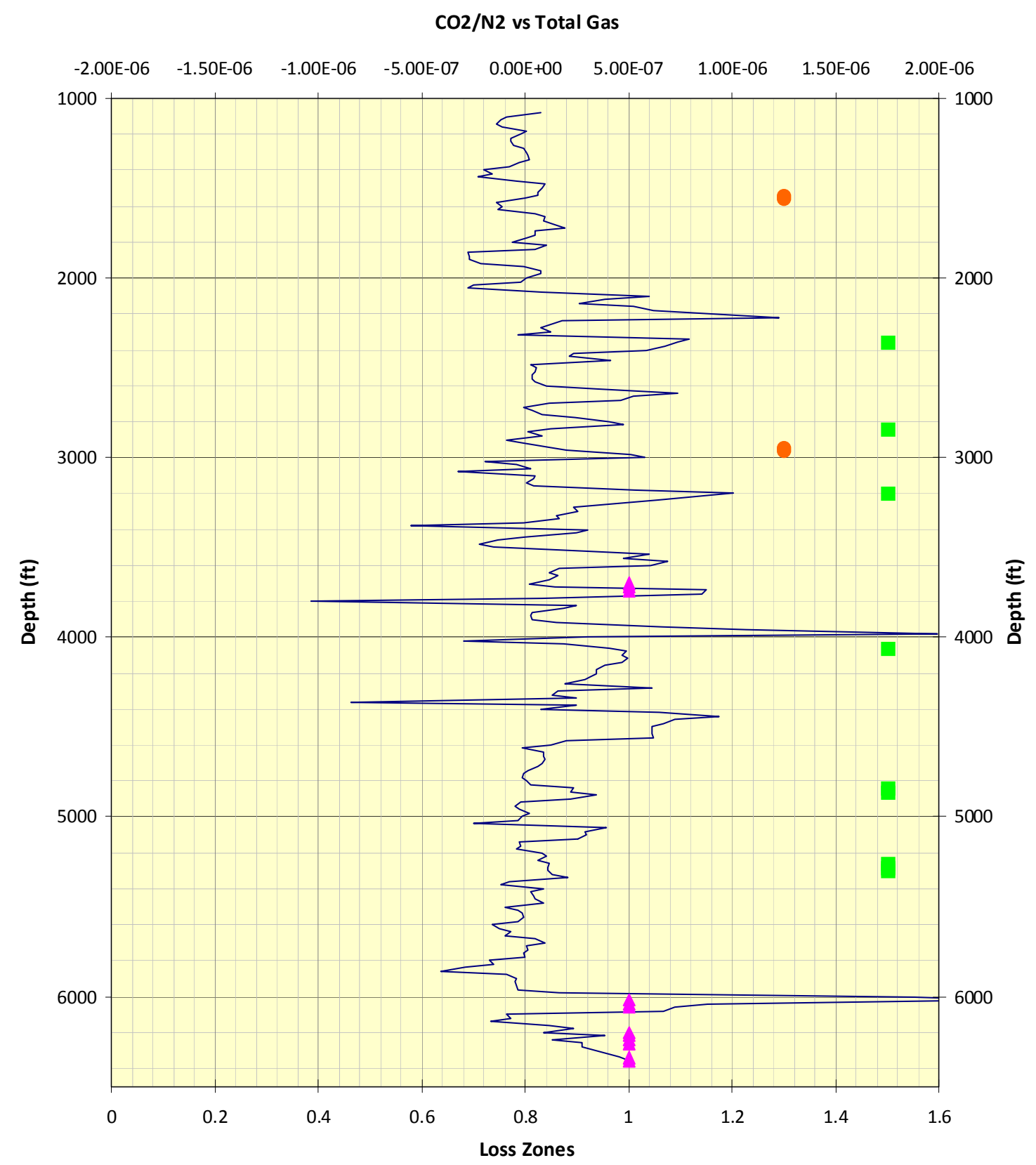

\begin{tabular}{|llll}
\hline & $\mathrm{CO} 2 / \mathrm{N} 2$ vs Total Gas $\quad \Delta$ Lost Circulation $\quad$ Felsic Dikes $\quad$ Altered Zones \\
\hline
\end{tabular}

Figure 13: Plot of change in ratio with lost circulation, dikes and altered zones for Coso well 68-20. 
The Coso data used in the analysis was evaluated for statistical significance of fractured zones using permeability (change in the ratio of $\mathrm{CO}_{2} / \mathrm{N}_{2}$ versus total gas), absolute values of the permeability, and the ratios of $\mathrm{C}_{2} / \mathrm{H}_{2}$ and $\mathrm{CO}_{2} / \mathrm{N}_{2}$, as presented in Table 4 . The ANOVA evaluation found that while there was no clear relation between permeable zones between wells there was a relationship between the absolute value of the permeability. Ten of the 21 wells showed statistical significance between fracture and non-fracture zones at a confidence interval of 85 percent, with seven of those showing statistical significance at a 95 percent confidence interval. The CO2/N2 ratio showed the greatest relationship between wells as a predictor of fracture location. Thirteen of the 21 wells showed statistical significance between permeable and impermeable zones at a confidence interval of 85 percent, with 11 of those showing statistical significance at a 95 percent confidence interval.

For the non-Coso wells similar relationships were found. Two of the five wells showed a statistical significance between fracture and non-fracture zones using the change in the ratio versus total gas (permeability) and the ratio of $\mathrm{CO}_{2} / \mathrm{N}_{2}$, at a confidence interval of 90 percent. Three of the wells indicated a statistical significance to the absolute permeability to a confidence interval of 95 percent. For the ratio of $\mathrm{CO}_{2} / \mathrm{H}_{2}$ four out of the five wells indicated a statistical significance between fracture and non-fracture zones at a confidence interval of 90 percent. 
Table 4: ANOVA Summary for Permeability Ratios Coso Permeability ANOVA Summary

\begin{tabular}{|c|c|c|c|c|}
\hline Well & Permeability & $\begin{array}{c}\text { ABS } \\
\text { Permeability }\end{array}$ & $\mathrm{CO} 2 / \mathrm{H} 2$ & $\mathrm{CO} 2 / \mathrm{N} 2$ \\
\hline $23 \mathrm{~A}-19$ & 0.143 & 0.939 & 0.013 & 0.000 \\
\hline $24 A-8$ & 0.882 & 0.756 & 0.716 & 0.433 \\
\hline $33-7$ & 0.849 & 0.002 & 0.728 & 0.011 \\
\hline $38 C 9$ & 0.173 & 0.035 & $\mathrm{~N} / \mathrm{A}$ & 0.547 \\
\hline 38D9 & 0.263 & 0.227 & 0.642 & 0.395 \\
\hline $41 \mathrm{~B}-8$ & 0.082 & 0.000 & 0.381 & 0.000 \\
\hline 46A19RD & 0.299 & 0.007 & 0.292 & 0.079 \\
\hline $47 A-8$ & 0.761 & 0.740 & 0.824 & 0.032 \\
\hline 47A-8RD & 0.179 & 0.403 & 0.893 & 0.499 \\
\hline 51B16 & 0.196 & 0.699 & 0.991 & 0.212 \\
\hline $52-20$ & 0.616 & 0.370 & 0.103 & 0.000 \\
\hline $54-7$ & 0.673 & 0.931 & 0.065 & 0.037 \\
\hline 54-7RD & 0.747 & 0.084 & 0.648 & 0.939 \\
\hline 67-17D & 0.347 & 0.013 & 0.815 & 0.001 \\
\hline $68-6$ & 0.789 & 0.641 & 0.465 & 0.108 \\
\hline $68-20$ & 0.000 & 0.005 & 0.000 & 0.000 \\
\hline $73-19$ & 0.328 & 0.148 & 0.007 & 0.000 \\
\hline $83 B-16$ & 0.029 & 0.051 & 0.000 & 0.000 \\
\hline $86-17$ & 0.120 & 0.332 & 0.460 & 0.705 \\
\hline $88-20$ & 0.342 & 0.911 & 0.104 & 0.561 \\
\hline $84-30$ & 0.036 & 0.029 & 0.159 & 0.000 \\
\hline \multicolumn{5}{|c|}{ Non-Coso Wells } \\
\hline $87-29$ & 0.689 & 0.409 & 0.055 & 0.013 \\
\hline $\mathrm{K}-33$ & 0.604 & 0.001 & 0.801 & 0.293 \\
\hline T-2 & 0.041 & 0.235 & 0.075 & 0.782 \\
\hline $\mathrm{K}-21$ & 0.061 & 0.009 & 0.045 & 0.656 \\
\hline $88-28$ & 0.421 & 0.011 & 0.034 & 0.034 \\
\hline
\end{tabular}

$\operatorname{Pr}>\mathrm{F}<0.05$

$\operatorname{Pr}>\mathrm{F}<0.10$

$\operatorname{Pr}>\mathrm{F}<0.15$ 


\subsection{Precursors to Fractures}

For select fracture locations we plotted $\mathrm{H}_{2} \mathrm{O}, \mathrm{H}_{2} \mathrm{~S}$, and $\mathrm{CO}_{2}$ concentrations to evaluate if there were peaks in the concentrations prior to fracture locations. Figures $14 \mathrm{a}$ and $14 \mathrm{~b}$ present the results of the plotting. It can be seen that while there are peaks in the concentrations for each of the species centered on the fracture locations there does not appear to be a wide "halo" effect or a steady increase in the concentrations as the fracture is approached.
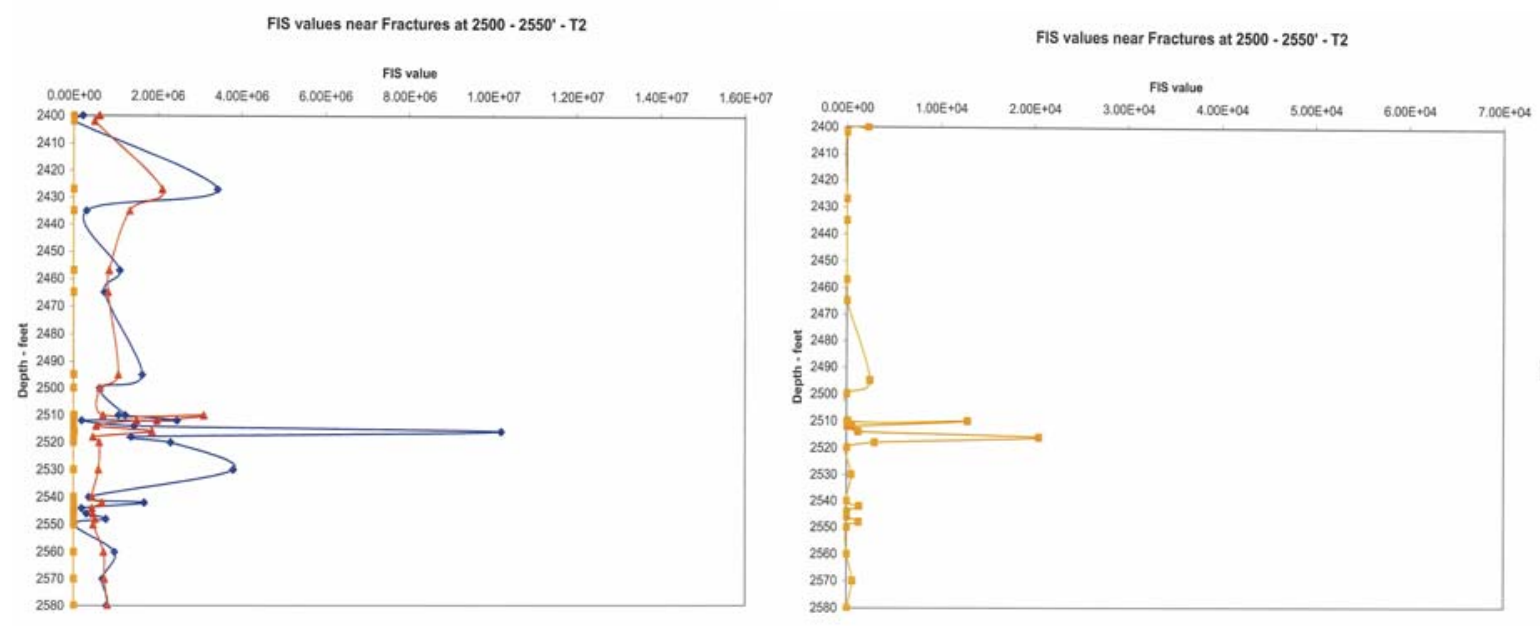

FIS values near Fractures at $4110-4140^{\circ}-$ T2 $^{\circ}$

FIS valuos near Fractures at $4110 \cdot 4140^{\prime} \cdot \mathrm{T}^{2}$
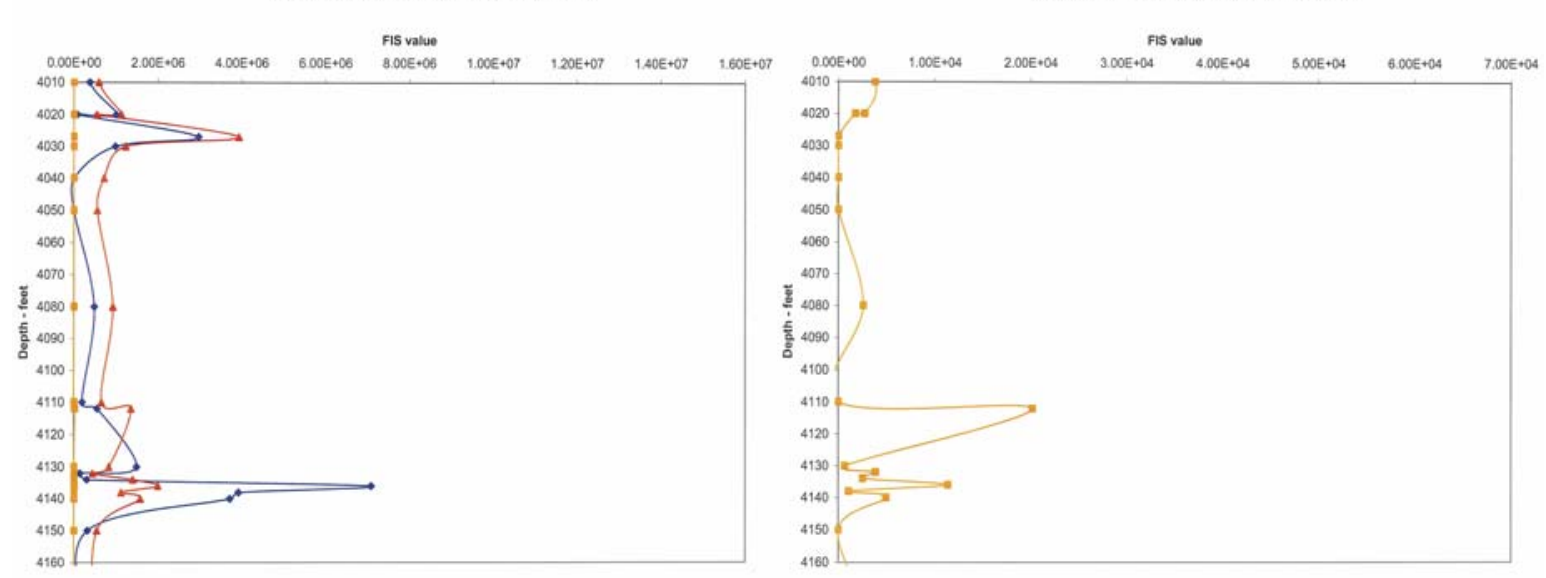

Figure 14a: Specific fracture locations in Well T2. The plots are of the concentrations of $\mathrm{CO}_{2}$ shown in red, $\mathrm{H}_{2} \mathrm{O}$ shown in blue, and $\mathrm{H}_{2} \mathrm{~S}$ shown in yellow. 
Fis value

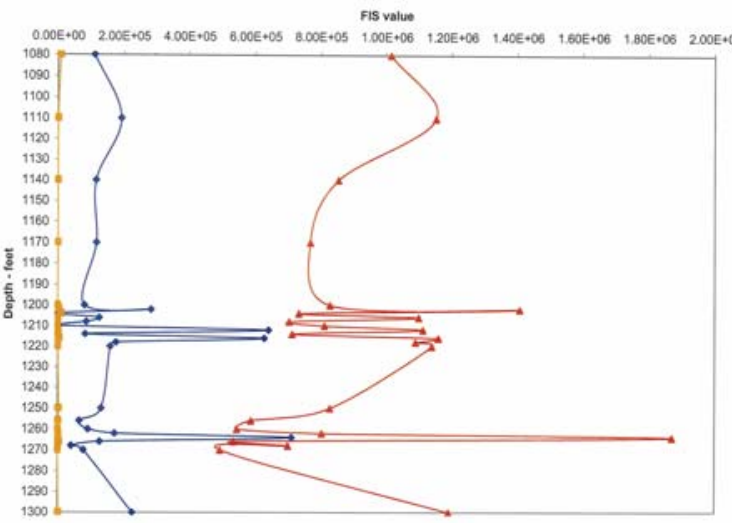

FIS values near Fractures at $2100-2210^{\circ}$ - Glass Mtn well 88-28

Fis value

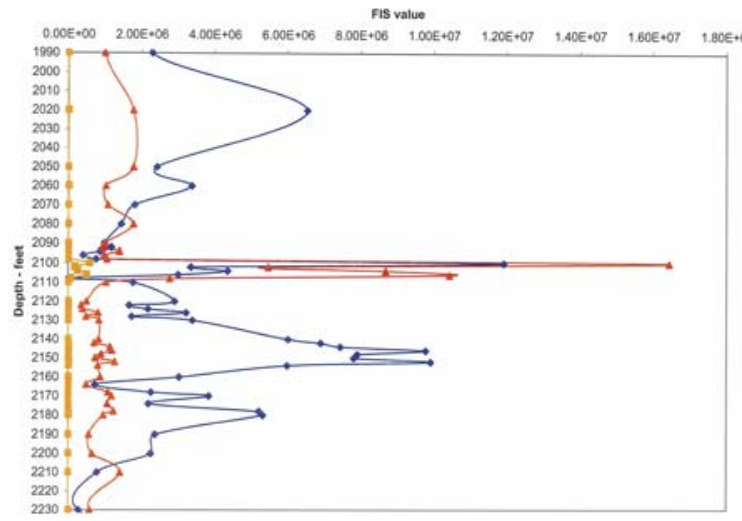

FIS values near Fractures at $1200 \cdot 1220^{\prime} \& 1250.1270^{\circ}$. Glass Mtn well 89.28

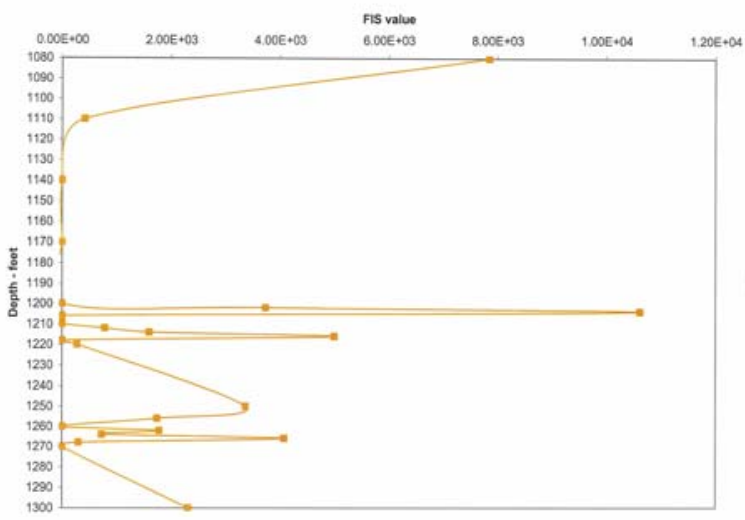

FIS values near Fractures at $2100 \cdot 2210^{\circ}$ - Glass Mtn well 88.28

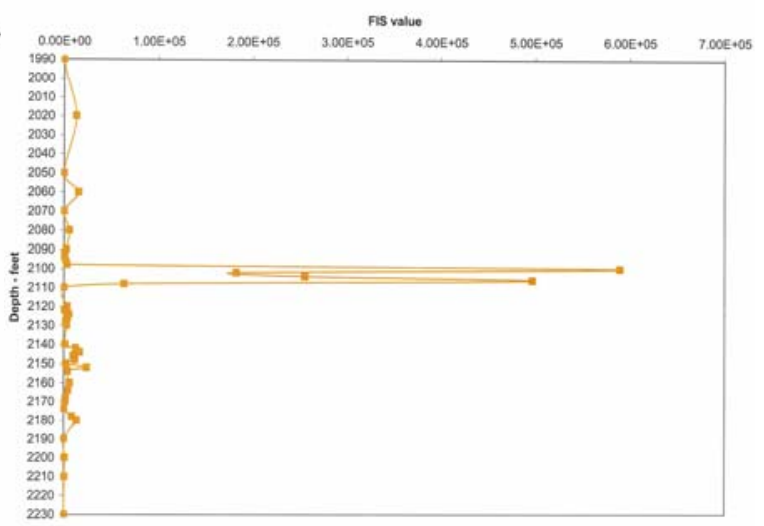

Figure 15: Fracture locations for Well 88-28. The plots are of the concentrations of $\mathrm{CO}_{2}$ shown in red, $\mathrm{H}_{2} \mathrm{O}$ shown in blue, and $\mathrm{H}_{2} \mathrm{~S}$ shown in yellow.

The ability to identify a fracture would be based upon the sampling interval as shown in Figures 14a and 14b. Previous studies have indicated a sampling interval of 20 feet would produce results similar to a sampling interval of 10 feet (Dilley, 2009). As seen in the figures, the thickness of fracture zones needs to be on the order of a few feet to be observed in the FIS signature particularly if the sampling interval is 10 feet. As the sampling interval is increased the size of the fracture zone seen in the FIS signature would necessarily have to be larger than in the 10 foot sampling interval. 


\subsection{INTERPRETATIONS}

Locations of fractures are identifiable on the FIS logs as peaks in the majority of chemical species as evident by the correlation in the wells studied of the FIS peaks and the noted fractures and veins. Not only are the correlations observed spatially on the logs but also via statistical analysis it was shown that for certain chemical species the average concentration for fractures is significantly different than the average concentration in non-fracture areas.

The peaks in the concentration may also represent the variability in the precision of the measurements. Based on studies conducted on FIS samples from Coso Geothermal Field and fluid inclusion standards precision is about 25 to 35 percent (Dilley, 2009). The percent difference in the average for select species is greater than the precision noted for the Coso samples. The FIS peaks appear to readily correlate to veins and to a lesser degree to fractures which may be due to the infilling material in a vein having a greater density of fluid inclusions than the material surrounding an open fracture.

Results of current research on the statistical correlations between FIS peaks and fractures indicate that the best species to identify fractures are $\mathrm{H} 2$, mass $3, \mathrm{CH}_{4}$ (mass 16), $\mathrm{H}_{2} \mathrm{~S}, \mathrm{CO}_{2}$, and $\mathrm{SO}_{2}$ (mass 64). See Table 3 for the ANOVA statistics. These results indicated that to at least a 90 percent confidence interval and in most cases, a 95 percent confidence interval that the average concentration for each of these species was different in fracture areas then in non-fracture areas.

These results were based on already knowing the location of fractures and non-fracture areas. In order to identify fracture locations in a well a routine was developed whereby the average concentration for all the samples for a select species was calculated. This average was subtracted from each sample value and the result was either positive (above the average concentration) or negative (below the average concentration). For each sample and the six species discussed above this was conducted in each well. The routine through a series of IF/Then statements give a value of 1 to each species that has an above average concentration and a 0 to each species with a below average concentration. The results are summed and range from 0 (no species above the average concentration) to 6 (all species above the average concentration). An ANOVA statistical evaluation was conducted to determine if the results for 2 or more or 3 or more species above the average concentration was statistically similar to the fracture location dataset. Table 5 presents the results of the ANOVA statistical evaluation. 
Table 5: ANOVA Statistics for the routine

\begin{tabular}{|c|c|c|}
\hline Well & 2 or more & 3 or more \\
\hline $87-29$ & 0.058 & 0.008 \\
\hline T-2 & 0.132 & 0.276 \\
\hline K-21 & 0.366 & 0.814 \\
\hline K-33 & 0.026 & 0.032 \\
\hline $88-28$ & 0.0008 & 0.00002 \\
\hline $17 \mathrm{~A}-6$ & 0.00004 & 0.00001 \\
\hline
\end{tabular}

$$
\begin{aligned}
& \operatorname{Pr}>\mathrm{F}<0.05 \\
& \operatorname{Pr}>\mathrm{F}<0.10 \\
& \operatorname{Pr}>\mathrm{F}<0.15
\end{aligned}
$$

It can be seen that for Wells K-33, 88-28 and 17A-6 this routine would give a better than 95 percent confidence that fracture dataset and the routine dataset are similar. For Well 87-29 the confidence interval ranges from 94.2 percent to greater than 95 percent. For Well T-2 the confidence interval ranges from 72 percent to 87 percent. For Karaha's Well K-21 the dataset were not statistically similar.

For predicting the actual location of a fracture using this routine, we evaluated how many times the routine actually located a fracture where there was a fracture and indicated a non-fracture areas. The routine ranged from 42 to 66 percent correct in identifying fracture locations and non-fracture locations. This suggests that there needs to be refinement in the routine in terms of what is the logic test for each species. In other words what would be considered the concentration in a fracture area versus a nonfracture area? In the routine presented it was based on the simplest case: concentration above or below the average for all of the samples. This average would be somewhere between the average concentration for fracture locations and non-fracture locations.

Based on the correlation of peaks in the FIS signature and the occurrence of certain minerals, it seems that $\mathrm{CO}_{2}, \mathrm{H}_{2} \mathrm{~S}$, and to a lesser degree $\mathrm{H}_{2} \mathrm{O}$ are species that would indicate fracture locations. Generally, $\mathrm{H}_{2} \mathrm{~S}$ seems to be associated with open fractures and pyrite mineralization, and with the production zone in Steamboat (the depths studied in the other wells do not intersect a production zone). Steamboat has sulfide mineralization (stibnite) occurring as fracture infilling and $\mathrm{H}_{2} \mathrm{~S}$ has the highest confidence interval (0.001) that the average concentration is different between fracture and nonfracture areas.

Boiling has occurred in Karaha (Moore et al, 2008). For Well K21 which is still liquid dominated, the average concentration of $\mathrm{H}_{2} \mathrm{O}$ in fracture areas is higher than in non- 
fracture areas. In the other two wells in Karaha which are vapor dominated, $\mathrm{H}_{2} \mathrm{O}$ average concentrations in fracture areas are slightly lower than in non-fracture areas. Steamboat Springs well has a very low difference in the concentration of $\mathrm{H}_{2} \mathrm{O}$. A similar trend occurs in Glass Mountain as in Karaha where Well 88-28 has a large difference in $\mathrm{H}_{2} \mathrm{O}$ average concentration but Well 17A-6.

For Karaha Wells the $\mathrm{CO}_{2} / \mathrm{N}_{2}$ ratio or the change in the ratio had a 95 percent or greater confidence interval that the ratio average was different in fracture and non-fracture areas. This ratio is based on boiling occurring in the system and there is additional evidence from the vapor-rich inclusions that boiling has occurred in this system.

Although there did not appear to be precursors to fractures based on our analysis there does appear to be about a 10 to 20 foot zone at each of the fracture locations selected. This suggests that a fracture can be picked out within about 10 to 20 feet. The "halo" around a fracture appears to be on this order particularly for larger fractures. 


\subsection{CONCLUSIONS}

Results indicate the following:

1) Fractures, veins and vuggy areas can be identified on FIS logs by distinct strong peaks (increase concentration) in multiple chemical species.

2) The bulk analysis of volatiles within fluid inclusions corresponds with several types of fracture infilling minerals including quartz, calcite, stibnite, and pyrite. Certain species such as $\mathrm{H}_{2} \mathrm{~S}$ and $\mathrm{CO}_{2}$ can be useful fracture indicators depending on the mineral assemblages.

3) There is a statistical difference in the average fluid inclusion gas concentration in select species between fracture and non-fracture areas. Species useful include: $\mathrm{H}_{2}, \mathrm{H}_{2} \mathrm{~S}, \mathrm{CO}_{2}$, and $\mathrm{SO}_{2}$ with other species at a lower confidence.

4) Ratios of $\mathrm{CO}_{2} / \mathrm{N}_{2}$ and $\mathrm{CO}_{2} / \mathrm{H}_{2}$ appear to work in wells where boiling is evident.

5) The "halo" around fracture appears to be on the order of 10 to 20 feet.

6) Although a routine was not determined to identify fractures there may, based on the ANOVA analysis, a way to crate a routine.

7) Research suggests that FIS analysis can be used to find fracture zones and be used to identify areas for fracture simulation in EGS. 


\section{REFERENCES}

Adams, M.C., J.N. Moore, S. Bjornstad, and D.I. Norman (2000). Geologic History of the Coso Geothermal System. Proceedings: World Geothermal Congress, Kyushu-Tohoku, Japan, 2000, 2463-2469.

Arehart, G.B., Coolbaugh, M.F., and Poulson. S.R. (2003), Evidence for a magmatic source of heat for the Steamboat Springs geothermal system using trace elements and gas geochemistry: Geothermal Resources Council Transactions, v 27, p. 269-274.

Bacon, C.R., and W.A. Duffield (1980). Special Section: Geothermal Investigations in the Coso Range, California. Journal of Geophysical Research 85: 2379-2516

Bacon, C.R., R. MacDonald, and R.L. Smith (1981). Pleistocene High-Silica Rhyolite of the Coso Volcanic Field, Inyo County, California. Journal of Geophysical Research 86: 10223-10241.

Carrier, Daniel L., (1989) Hydrothermal Alteration and Well Lithologies for Glass Moutain Wells: GMF 68-8, GMF 31-17 and GMF 17A-6, Unocal Memorandum

Dilley, Lorie M., David I. Norman \& Brian Berard, (2004), Fluid Inclusion Stratigraphy: A New Method for Geothermal Reservoir Assessment - Preliminary Results; Proceedings of the $29^{\text {th }}$ Annual Stanford Geothermal Workshop, p. 230-238.

Dilley, Lorie M. and David I. Norman (2004) Fluid Inclusión Stratigraphy: Determining Producing from Non-Producing Wells, Geothermal Resources Council Tranactions, 18, p.387-391.

Dilley, Lorie M., and Norman, D.I, (2007), "Identifying Fractures and Relative Ages Using Fluid Inclusion Stratigraphy: Preliminary results," Geothermal Resources Council Tranactions, 31.

Dilley, Lorie M., David I. Norman, and Lara Owens, (2008) "Identifying Fractures and Relative Ages Using Fluid Inclusion Stratigraphy: Department of Energy Report. DEFG36-06G016057 A000

Dilley, Lorie M. (2009), Fluid Inclusion Stratigraphy, A New Method for Geothermal Reservoir Assessment, New Mexico Tech Ph.D. 
Donnelly-Nolan, Julie M., (2002), Tectonic Implications of Geologic Mapping, Medicine Lake Volcano and Vicinity, Northern California; GSA Cordilleran Section - 98th Annual Meeting, May 13-15, 2002.

Donnelly-Nolan, Julie M., (1990) Geology of Medicine Lake Volcano, Northern California Cascade Range, Geothermal Resources Council Transactions, 14, p. 1395-1396.

Faulds, J.E., Garside, L., Johnson, G., Muehlberg, J., and Oppliger, G.L. (2002), Geologic setting and preliminary analysis of the Desert Peak - Brady geothermal field, western Nevada: Transactions Geothermal Resource Council, v. 26, p. 491-494.

Hall, D. (2002). Fluid Inclusion Technologies, Inc. http://www.fittulsa.com/

Jones, J. Claude (1912), The Occurrence of Stibnite at Steamboat Springs, Nevada. Science, Volume 35, Issue 907, pp. 775-776

Kuehl, Robert O., (2000). Design of Experiments: Statistical Principles of Research Design and Analysis, $2^{\text {nd }}$ Edition. New York: Duxbury.

Kurilovitch, Lynne, Dave Norman, Matt Heizler, Joe Moore, and Jess McCulloch (2003). ${ }^{40} \mathrm{Ar} /{ }^{39} \mathrm{Ar}$ Thermal History of the Coso Geothermal Field. Proceedings: Twenty-eighth Workshop on Geothermal Reservoir Engineering, Stanford University, Stanford, California.

Lutz, S.J., J.N. Moore, M.C. Adams, and D.I. Norman (1999). Tracing Fluid Sources in the Coso Geothermal System Using Fluid-inclusion Gas Chemistry. Proceedings: Twenty-fourth Workshop of Geothermal Reservoir Engineering, Stanford University, Stanford, California.

Moore, D. E., C. A. Morrow, et al. (1987). "Fluid-rock interaction and fracture development in "crystalline" rock types." Open-File Report - U. S. Geological Survey Report No: OF 87-0279.

Moore, J.N., R. Allis, J.L. Renner, D. Mildenhall, J. McCulloch (2002) Petrologic Evidence for Boiling to Dryness in the Karaha-Telaga Bodas Geothermal System, Indonesia, Proceedings: Twenty-second Workshop of Geothermal Reservoir Engineering, Stanford University, Stanford, California. 
Moore, J.N., R Allis, M. Nemcok, T.S. Powell, C.J. Bruton, P.E. Wannamaker, I.B. Raharjo, and D.I. Norman (2008) The Evolution of Volcan-Hosted Geothermal Systems Based on Deep Wells From Karaha-Telaga Bodas, Indonesia, American Journal of Science Vol. 308, January.

Nemcock, M., J.N. Moore, R. Allis, J. McCulloch (2004) Fracture Development within a Stratovolcano: the Karaha-Telaga Bodas Geothermal Field, Java Volcanic Arc, Geological Society, London, Special Publications, v. 231, p. 223-242.

Norman, D.I., Nigel Blamey, and Joseph N. Moore (2002). Interpreting Geothermal Processes and Fluid Sources from Fluid Inclusion Organic Compounds and $\mathrm{CO}_{2} / \mathrm{N}_{2}$ Ratios. Proceedings: Twenty-seventh Workshop on Geothermal Reservoir Engineering, Stanford University, Stanford, California.

Norman, D.I., J.N. Moore, J. Musgrave, 1997. Gaseous species as tracers in geothermal systems: Proceedings: Twenty-second Workshop of Geothermal Reservoir Engineering, Stanford University, Stanford, California.

Norman, DI, Lorie Dilley, and Jess McCulloch, 2005, Displaying and Interpreting Fluid Inclusion Stratigraphy Analyses on Mudlog Graphs: Thirtieth Workshop on Geothermal Reservoir Engineering Stanford University, Stanford, California, Jan. 30-Feb. 2, 2005.

Silberman, M. L., White, D. E., Keith, T. E. C., and Docktor, R. D. (1979). "Duration of hydrothermal activity at Steamboat Springs, Nevada, from ages of the spatially associated volcanic rock." U. S. Geological Suvey Professional Paper 458-D: 14 p.

White, D. E., Thompson, G. A., and Sanberg, C. S. (1964). "Rocks, structure, and geologic history of Steamboat Springs thermal area, Washoe County, Nevada." U. S. Geological Survey Professional Paper 458-B: 63 p. 